University of Louisville

ThinkIR: The University of Louisville's Institutional Repository

Electronic Theses and Dissertations

1942

\title{
The Louisville, Kentucky, Home for the Aged and Infirm : a study of an institution in transition.
}

Irving M. Lipetz 1913-2012

University of Louisville

Follow this and additional works at: https://ir.library.louisville.edu/etd

Part of the Gerontology Commons, and the Social Work Commons

\section{Recommended Citation}

Lipetz, Irving M. 1913-2012, "The Louisville, Kentucky, Home for the Aged and Infirm : a study of an institution in transition." (1942). Electronic Theses and Dissertations. Paper 1822.

https://doi.org/10.18297/etd/1822

This Master's Thesis is brought to you for free and open access by ThinkIR: The University of Louisville's Institutional Repository. It has been accepted for inclusion in Electronic Theses and Dissertations by an authorized administrator of ThinkIR: The University of Louisville's Institutional Repository. This title appears here courtesy of the author, who has retained all other copyrights. For more information, please contact thinkir@louisville.edu. 


\section{UNIVERSITY OF LOUISVILIE}

THE LOUISVILLE, KENTUCKY, HOLE FOR THE AGED AND INFIRM

A STUDY OF

\section{AN INSTITUTION IN TRANSITION}

\section{A Dissertation}

Submitted to the Faculty

- Of the Graduate School of the University of Loulsvilie

In Partial Fulfillment of the

Requirements for the Degree

of

Master of Science in Social Administration

Division of Social Administration

by

Irving M. Lioetz 
NAME OF STUDENT: Irving M. Lipetz

TITLE OF THESIS: The Loulsville, Kentucky Home for the Aged and Infirm: A Study of an Institution in Transition

APPROVED BY READING COMITTEE COMPOSED OF THE FOLLOWING MENBERS :

NAME OF DIRECTOR:

DATE: $\quad$ May 22, 19 $\$ 2$ 


\section{AN ACKNOWLEDGIENT}

The writer wishes to acknowledge his gratitude to Mr. John J. Cronin for his kind assistance, encouragement and personal guldance; to Mrs. Elizabeth B. Glenn and members of the staff of the Home for the Aged and Infirm for their aid and suggestions; to the staff of the Department of Public Welfare for placing material at my disposal; and especially to my wife without whose help this study would not have been possible. 
TABLE OF CONTENTS

Chapter

Page

Introduction

1

I Historical Background

5

II Legislation

A. Prior to $1872 \quad 20$

B. 1873 through 1941

III Aơministration

A. 1832 to $1930 \quad 38$

B. 1930 through 1941

IV Population

A. 1857 through 1941 7I

B. Survey of the Residents in 79 the Home on Jenuary 1, 1942

$V$ liedical Care $\quad 99$

VI The OId Age Assistance Program 121

$\begin{array}{ll}\text { Conclusions } & 129\end{array}$

Bibliograohy $\quad 135$

$\begin{array}{ll}\text { Appendix } & 140\end{array}$ 


\section{LIST OF TABLES}

Table

Page

I Pooulation of the Home for the Aged and

77

Infirm between september 1, 1932, through August 31, 1941 (Showing Admissions, Deaths, Discharges and Average Resident Population

II Residents of the Home for the Aged and Infirm on January 1, 1942, by Sex and Race, According to Number and Percent

III Ages of the Residents of the Home for the

81 Aged and Infirm on January 1, 1942, by Number and Percent

IV Length of Stay of Residents in the Home for the Aged and Inf1rm on January 1, 1942

$V$ Sources of Referrals Other Than the Municipal Bureau of Social Service of Residents of the Home for the Aged and Infirm on January $I$, 1942

VI Educational Attainments of Residents of the Home for the Aged and Infirm on January 1 , 1942

VII Agencies which had assisted Residents of the Home for the Aged and Infirm on January 1,1942

VIII Total Grants, Number of Recioients and

Average Monthly Grant oer Recipient of Old Age Assistance in Kentucky from July I, 1936, through June 30, 1941

IX Number of Reciplents, Amount Granted and Average Monthiy Grant per Reciolent of Old Age Assistance in Jefferson County, Kentucky, in May, 1939, August, 1941, and March, 1942 
THE LOUISVILLE, KENTUCKY HONE FOR THE AGED AND INFIRM A STUDY OF AN INSTITUTION IN TRANSITION 
INTRODUCTION 


\section{INTRODUCTION}

Th1s study has been undertaken in an effort to clarify the present position of the Loulsville, Rentucky Home for the Aged and Infirm in our constantly changing social scene and to enable the drawing of some conclusions which may prove helpful in planning for the future role of the institution.

Since the passage of the Social Security Act, with 1ts two programs designed to meet the needs of the aged, there has been considerable discussion concerning the odvisability of converting almshouses and homes for the aged into hospitals for the chronically 1ll. As Loulsville does not have a chronic hospital, a purpose of this study has been to determine the feasibility of converting the Home for the Aged and Infirm into a hospital of this type.

In making a study of the institution, it is felt advisable that an immediate program as well as a long range program be considered. Closely allied with any proposed program, such factors as admission policles to be adopted, personnel changes which may be deemed necessary and alterations in the physical plant must be studied. The method used in this study consists of an approach from several different aspects. Because of a lack 
of previously collected data, considerable emphasis has been placed on the historical background of the institution. An effort has been made to determine the prevailing social thinking at varlous periods during the one hundred years of the Home's existence as well as to detect any outstanding trends. Social leglslation has been reviewed as it has affected the institution. The various organizational arrangements and administrative policies have been noted. The make-up of the resident population, both past and present, has been given considerable attention as this has been felt necessary if any accurate conclusions are to be drawn. The effect of the Old Age Assistance program and its possible future influence has been considered. Finally, the medical care which the residents recelve and the arrangements and equipment of the physical plant have been carefully studied to determine what changes may be necessary for the future role of the institution.

The primary source of material has been the Annual Reports of the Home and of the Department of Welfare. It has been possible to secure only a limited amount of data concerning the institution prior to 1857 . There were several periods for which no Annual Reports could be secured, particularly from 1916 to 1930 . Whenever possible, material collected from newspaper clippings, city directories, or 
other similar sources, have been used to fill in the gaps. In making a survey of the resident population in the Home at the time of the study, the social case record as well as the medical chart of each resident was studied. Each resident's history was reviewed with the social worker at the Home in an effort to learn what the future plans of the residents might be.

In the following chapters this study will attempt to note some of the problems now facing the Home and to present some possible solutions. 


\section{CHAPTER I}

HISTORICAL BACKGROUND 
Historical Background

The history of the Home for the Aged and Infirm may be divided into three perlods namely, prior to 1875,1875 to 1930 and 1930 through 1941. The first of these perlods may be considered as the formative period, an era of original establishment and gradual expansion. Between 1875 and 1930 the institution continued to expand, a new bullaing was erected and there was a gradual shift in the policy concerning admissions. Th1s change in policy, which was partly caused by the development of specialized institutions, caused the Home to turn from a "catch all", to an institution primarily for the aged and the chronically 1ll. Nevertheless, many of those admitted might well have been cared for in other more specialized institutions or in their own homes had resources been avallable. Th1s second period 1s particularly significant since it witnessed the elimination of children as residents. During the last decade there has been a decided trend toward converting the institution from a home for the aged to a hospltal for the chronically incapacitated. In an effort to understand and interpret the underlying social philosophy as it influenced the Home, Its administration and its functioning, it seems essential that we review briefly public relief giving in this country. 
Public rellef has always been a part of our American system of government as the earliest colonists brought with them the Elizabethan poor law and a knowledge of English experience with work relief. They brought with them, also, as part of the Elizabethan poor law, the theory of local responslbility for the care of the poor. "Settlement laws," which fixed residence as a basis for establishing ellgibility for rellef and the requirement of work as a condition of relief are found in early records of New England town meetings.

The Ellzabethan poor law of 1601 recognized the state's obligation to those in need and the obligation of every community to provide some measure of public supoort for the destitute, but it penalized the poor who were given public ald. Acceptance of public support meant loss of many of the rights and privileges of citizenship just as a prison sentence did. Varlous deterrent methods such as inadequate relief and public humliation were used to prevent the children of the indigent from becoming paupers. In adaltion to relief for the "Impotent" and the "setting on work" of the able bodied, the law provided for the establishment of "convenient dwellings" for the old and feeble. These latter orovisions resulted in the impetus toward the erection of numerous

1

Grace Abbott, From Relief to Social Security, (Ch1cago: The University of Chicago Press, 1941), po.5 f.

2

Ib1d., pp. $6 f$. 
English workhouses, from which our American almshouses have 3 cescended.

The first English workhouse was erected in Bristol in 1697 and admission was restricted to able bodied persons who could not secure assistance elsewhere. The Bristol plan proved highly satisfactory and a marked decrease in vagrancy and pauperism was noted. Following this initial success, many other English cities erected similar institutions. It should be noted that these institutions were restricted to the admissions of able bodied persons. However, the Gilbert Act, passed in 1788, authorized each parlsh to create a poorhouse for all classes of paupers, except the able bodled. Those able to work were to be employed near their own homes. The Gilbert Act led to the "mixed workhouse", which became the dumping ground for persons of all ages, regardless of their mental or ohysical condition.

Despite the widespread acceptance of the OId English Poor Law, periodic efforts were made in both this country and in England to abolish public relief giving. Reverend Joseph Townsend, in his Dissertation on the Poor Laws, pubIIshed in 1786, regarded 1dleness the immediate cause of destitution. He belleved in the social value of the fear of

3

"Almshouse", Encyclopedia Americana, Vol. I, 1941 4 Ibid. 
hunger, since he thought this fear was the sour that drove the poor to work. Reverend Townsend favored haphazard and uncertain relief by the rich.

Thomas Melthus, the economist, expounded the theory that the destitute man was to blame for his poverty and that he should be denied all public relief and be left to the "uncertain support of private charity". If the well to do could be taught to restrain their generous impulses and pubIic relief was abolished, the poor would be made to meet their own needs or suffer the consequences. Malthus' arguments still survive in some quarters even today.

In the 1820's there was much discussion throughout this country concerning "cures for pauperism". In 1824, the Secretary of State of New York submitted to the legislature a report in which he stated that the extensive use of almshouses instead of home rellef would end the destitution and "pauperism" of the state of New York, to which he believed "outdoor relief" contributed. Following the example of New York, almshouses were bullt in county after county in state after state during the remainder of the 19 th century.

5

Grace Abbott, op. cit., ‥ 7 .

6 Ibid., pp. $7 \mathrm{f}$.

7

Ib1d., p. 8. 
Our own Home for the Aged and Inf1rm was a product of this period. Although it has not been possible to determine exactly when the city's first institution of this type was built, there is evidence that a combined Poor and Workhouse was in operation as early as 1832 .

The British Royal Commission of 1834 formulated the 1dea of conscious deterrence in the treatment of poverty, a pollcy which st1ll has many supporters. It was the desire of the Commission to make rellef as unattractive as possible and it therefore advocated low standards of Pinancial assistance and workhouse tests for applicants for rellef. How effectively these policies influenced the thinking of our Louisville leaders may be clearly seen by their emphasis on work by residents in the institution.

During the latter half of the 19 th century a trend was noted in the shifting of some of the burden from the local community to the state government. This was particularly noticeable in the provisions for certain special groups. Under the leadership of Dorothea Dix state hospitals were provided for the insane. As the result of the efforts of Samuel Gridley Howe special state ald was provided for blind, deaf and feeble minded children and under his leadership large numbers of children were gradually removed from local poorhouses and from families too poor to give them the

8

Loulsville City Directory, (Louisville: Richard W. Ot1s, 1832), p. 144 . 
9

special training needed. William P. Letchworth and JoseohIne Shaw Lowell instigated programs for dependent children and were instrumental in bringing about the removal of many chilaren from poorhouses.

Kentucky kept pace with the trends and during the 19 th century mental hospitals and specialized institutions came Into being. The Kentucky School for the Blind, in Louisville, was opened in 1842 and the Eastern Lunatic Asylum was created in 1822 .

Many persons needing specialized care were admitted to the Loulsville Clty Almshouse, as 1t was called, primarily because of a lack of institutions for their care. There were chilaren in the institution as late as 1900, although few children were admitted after 1886. Even today there are many individuals in the home who have been diagnosed as senile but the state mental hospltals are too crowded to admit them.

The twentieth century has seen the enactment of much social legislation and a continued trend toward greater federalstate participation. Laws concerning workman's compensation, blind pensions, mother's ald and old age pensions were enacted prior to the depression of 1929.

9

Edith Abbott, Public Assistance, (Chicago: University of Chicago Press, 1940), Vol. I, po. $509 \mathrm{f}$.

10

Ib1d., p. 510.

11

Ib1d., p. 511. 
The depression of 1929 brought with it the greatest unemployment problem the country has ever experienced. The existing relief system was inadequate to meet the increased demands for financial assistance. The private social agencies could not carry the burden and many communities lacked the funds necessary to carry out any adequate program of relief. The weaknesses of the old poor law system became very obvious. The local communities could not meet the financlal demands and in many instances the states could not assist since statutory provisions made the relief of the destitute the responsibility of the local community.

Desplte the inability of the local communities and the private agencies to cope with the problem there was considerable opoosition to any extension of public assistance. Many influential oitizens continued to insist that private charity could adequately provide for those in need and vigorously opposed the demand for large public relief funds. Th1s opinion was shared by the Chief Executive in Washington, President Hoover, who expressed his belief in the superior merits of private charity. $^{13}$ The national administration, in 1930 , felt that the community chests could take care of the situation and that the Red Cross could care for drought sufferers in the rural areas. Meanwhile some Congressmen began to

12

Ibid., p. 513.

13

Ibid., p. 514. 
urge a Federal appropriation for a works program.

Myron C. Taylor, chalman of the finance committee of the United States steel Corooration, expressed the views adopted by many in an address on January 27, 1931. Mr. Taylor stated that although there was considerable unemoloyment, there were few persons in real alstress. According to Mr. Taylor, the solution could be found if the Individual would accept whatever employment he could find and by his efforts, diligence and ambition raise himself to a better and more remunerative position. Man's field of occupation could always accommodate all who were willing to work and the slacker would have to give way to the man of action. 15 Thus, in 1931 , we still had many who agreed with the theories of Malthus and believed that the individual alone was responsible for his own predicament.

In July, 1932, the first federal relief act was en16

acted by the Hoover Administration. This act provided for federal state loans rather than grants in ald. The Reconstruction Finance Corooration was established with power to

14

Harry L. Hopkins, Spending to Save, (New York: W. W. Norton and Co., 1936), p. 20 .

15

Ib1d., p. 38 .

16

Ed1th Abbott, op. c1t., p. 728. (Emergency Rellef and Construction Act of 1932, approved July 21, 1932, Chap. 520,47 U. S. Statutes at Large 709 (72nd Cong. Ist sess.). 
make loans to the states for direct and work rellef programs, the amount of the loans being based on the extent of the need in the various states.

With the Inauguration of Franklin D. Roosevelt as Pres1dent in March, 1933, there was a decided change in the federal policy. On May 12, 1933, the administration passed a relief bill and shortly thereafter the Federal Emergency ReIlef Administration was established. This act provided for federal grants in aid to the states for their relief programs. In Noveinber, 1933, the Civil Works Administration was created to carry out a work relief program. It should be noted that the b1ll provided for both work and direct relief. In 1935 the Works Progress Administration was set up and at this time the Federal Government withdrew from the direct relief field, providing assistance only through a public works program. Thus, once again the burden of caring for "unemployables" and most of the unemoloyed was thrown back on the local community.

17

Edith Abbott, op. cit. p. 667.

18

Ib1d., p. 669. ("An Act to Provide for Cooperation by the Federal Govermment with the several States and Territories and $D$. of $C$. In Relieving the Hardshio and Suffering Caused by Unemployment, and for other purooses " aoproved 5-12-33, Chap. 30,48 U. S. Statutes at Large, 55 (73rd Cong., Ist session).

\section{9}

Edith Abbott, oo. c1t., p. 673.

20

Hopkins, op. cit., p. 166 (Emergency Relief Appropriation Act - 1935). 
In addition to the federal works program however, President Roosevelt submitted and Congress passed the Soc1al Security Act in 1935. 21 This was the President's permanent relief plan. On June 8, 1934, the President appointed the Committee on Economic Security and later in the same year an Advisory Council to this Committee. The reports of these two groups were submitted in January, 1935, and the Social Security Act was passed in August of that year.

The Social Security Act is probably the most important piece of social legislation ever enacted by this country. It should be noted that many of the provisions of the Act were not original. The first effective state old age assistance act was passed in 1923 and the first mother's aid laws were enacted in 1911. The 1mportance of the act lies in the fact that a nation-wide system was created through which each state could secure federal assistance in carrying out a broad program.

The Social Security Act set up three programs of pub110 assistance. These were Old Age Assistance, Ald to the Blind and Ald to Dependent Children. These three progrems

21

Grace Abbott, op. c1t., p. 228 (The Wagner Lewis B1II, 49 U. S. Statutes at Large, 620 (1935): 42 U.S.C.A., 1301 (1935). 22 Ib1d., pp. 199 f. 23 Ib1d., p. 229 . 
are administered by the several states, with the Federal Government acting in a supervisory capacity and matching funds on a specific basis. By means of this public assistance program, the Federal Government accepted at least part of the responsibility for caring for three large groups of the socalled "unemployables".

Title Two of the Act was amended in 1939 and is now entitled Federal old Age and Survivors Insurance; this is an insurance and not an assistance program. Qualified workers are entitled at retirement at age 65 to recelve monthly benefits, based on their past earnings. In certain instances widows, wives, children and dependent parents may be entitled to monthly insurance benefits. In those cases where no survivor is eligible for monthly benefits, a lump sum payment may be made. The law stipulated $\$ 10$ and $\$ 85$ as the minimum and maximum monthly benefits payable.

This section of the Act is actually a plon of forced saving and the funds are contributed jointly by the worker and his employer. It represents the efforts of the government to provide a plan to care for the average worker after he has lost, as a result of age, his ability to comoete in the labor market with his younger competitors. Rather than a haphazard future, dependent on savings, relatives or, as

24

Material concerning the orovisions of the Social Security Act has been secured from Compllation of the Social Security La.ws, Social Security Board, (Washington, D. C., 1941) 
a last resort, public assistance, the worker now has an opportunity to provide at least some measure of financial security for his declining years. And in addition, the plan also provides a cushion for the survivors of those workers who are victims of industrial accidents or who die before they reach 65 .

The Federal old Age and Survivors Insurance plan now affects some forty million workers and plans are belng made to extend coverage to an even greater number. At the present time large groups, such as farmers and domestics, are excluded. The benefits are also too low and there are several gaps, such as a lack of provision for the young widow between the time her children reach 18 and the time she becomes 65 .

Maternal and Child Health Services, Child Welfare Services, Services for Cripoled Children, Vocational Rehab1litation and Public Health Services, were provided for in other sections of the Social Security Act.

The Act is a planned, many sided attack on many of the problems facing the population. First of oll specialized services are provided for certain groups. Public health is given increased attention. A cushion is provided for the unemployed worker for a temporary period. The superannuated worker may receive monthly checks based on his past earnings. And supplementing these programs, three public assistance programs have been set up for those persons who fall to qualify under the other sections. It should be noted that none 
of the programs are exclusive and that an individual may oarticipate in more than one assistance program and receive Federal Old Age Insurance benefits at the same time.

Kentucky was among the first to avail itself of the opportunities afforded by the social security Act and passed legislation to quelify for Federal old Age Assistance funds. An unemployment compensation act was passed. Just this year the state has finally had legislation upheld permitting particlpation in the Ald to Dependent Chlldren and Ald to the Blind programs.

It was originally hoped that the old Age Assistance program would greatly lessen the number of persons in our almshouses and poor farms. In a later chapter we will discuss the effect the old Age Assistance program has had on our own Home for the Aged and Infirm and some of the reasons why this program has not proved more effective.

At the end of 1941, we had a well established Department of Public Welfare for the City of Loulsville, supervising the administration of the Home for the Aged and Infirm and controlling admissions to the Home through the Municipal Bureau of Social Service. The Home's staff was free to devote all of its time to the care of the residents rather than to the farm as had oreviously been the case. A social worker

25

See Page 126 for a discussion of the effect of old Assistance program on the Home for the Aged and Infirm. 
and a medical staff were attached to the institution. The Old Age Assistance program was having a l1mited effect upon the number of admissions. 
GHAPTER II

LEGISLATION 


\section{LEGISLATION}

\section{A. PRIOR TO 1872}

Kentucky, which was admitted to the Union in 1792 , was originally a part of virginia and in many respects adopted policies and legislation previously placed into operation by the mother state. It is known that an almshouse was established in Virginia as early as 1755 and that a Poor

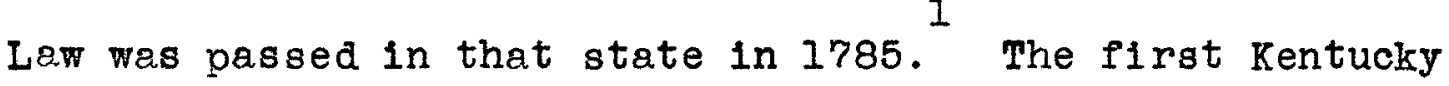
Poor Law, modelled after the Virginia law of 1785, was enacted in 1793. This law placed the responsibility for the care of the poor upon the county and on December 19, 1793, the Kentucky county courts were authorized to make a county levy for the relief of the poor who were not able to support themselves.

The town of Louisville was established following the aporoval of An Act For Establishing the Town of Loulsville at the Falls of the Oh1o by the Virginia Legislature in May, 1780. At the time of its establishment the total

1

Emil McKee Sunley, "The Kentucky Poor Law 1792-1936," (Unpublished Ph.D. Dissertation, School of Social Service Administration, University of Chicago, 1938), p. 128.

2

Ib1d., 0.98 .

3

Louise Hess Meyers, "A History of the Loulsville Clty Hosoital," (Unoublished M.A. thesis, Deoartment of Sociology, University of Louisville, 1936), D. 7 . 
population of the town was only thirty persons. By 1800 , the population had increased to 600 . The acquisition of Loulsiana by the United States in 1809 opened up the Mississiopi Valley for river trade. This new source of commerce, plus the location of the Ohio River Falls at Loulsvilie, wnich torced ill boats to stop end reload before going farther South, provided considerable impetus for a rapid population increase. In 1810 the population totalled 1300 and during the next decade there was an increase to 4000 persons.

Th1s tremendous increase in numbers produced problems which demanded community attention and the clty's first social institutions were founded. In 1817 the Louisville Hosoltal Company, the forerunner of our present General Hospital, was established to meet the increased demands for medical care. The City suffered a heavy loss of life as a result of a yellow fever epidemic and in 1822 a Board of Health was set uo to cope with this problem.

The Kentucky State Legislature passed 1ts f1rst poorhouse law in 1821 when permission was granted to the several counties to provide county poorhouses. The counties were

4

Ibid., p. 8 .

5

Ibid.

6

Ib1d., ‥ 11. 
permitted to purchase two hundred acres of land and to make a levy to cover the cost of the land, bulldings and repairs. A fit person was to be apoointed superintendent, with a reasonable compensation and he could compel the able-bodied poor to work on the poorhouse farm. The County Court was to make all rules and regulations concerning the government of the poorhouse, the purchase of raw materials and the disposal of the products. Following the pasage of this Act, the Jefferson County home was established in 1822.

The city's growth continuing at an ever increasing rate (the 1830 census listed 10,090 persons), the state legislature aporoved a charter for the City of Louisville on February 13, 1828. The Charter's orovisions indicated that the local government took cognizance of the 1821 state poorhouse law and included the right to erect and maintain a poorhouse.

The section of the 1821 charter, entitled powers of Mayor and Councilmen, reads as follows:

Be it further enacted.... That the Mayor and Counclimen of said city shall have and possess the powers hereinafter mentioned. .. Seventh, they shall have the power and it shall be their

7

Sunley, op. cit., po. $128 \mathrm{f}$.

8

Oliver H. Stratton and John M. Vaughan, A Collection of the state and Municlpal Laws in Force and Aoplicable to the Clty of Louisvilie, Ky., (Loulsvilie: C. Settle, 1857) p. 53. 


\begin{abstract}
duty to erect or procure a suitable building or bullaings for a poor house and workhouse, in which the indigent poor shall be comfortably provided for at the expense of said corporation, to be regulated and managed by suitable persons to be appointed by mayor and councilmen for that purpose; and in apartments distinct from the indigents and infirms, provision shall be made for confining common beggars, vagrants and all persons who may be sentenced for short periods of confinement by justices of the peace or by the mayor for breaches of the peace or for petty offences, where they shall be employed in such labor and made to perform such tasks as shall be directed by the ordinances of the mayor and councilmen. Persons committed to the workhouse shall be sent there by warrant.. There shall be a committee of the Board of Councilmen, or speclal overseers of the poor, to be estabilshed by the Board, who shall place poor persons in the poor house at their discretion, but the whole establishment shall be under the control and immediate care and subject to freguent visitation of the mayor and councilmen. 9
\end{abstract}

This enabling legislation afforded the city an opportunity to erect a single institution for both the indigent poor and petty offenders, vagrants and beggars. The "indigents and Infirms" were to be housed in separate quarters, however, and the poorhouse was to be administered by a Committee of the Board of Councilmen or special overseers of the poor.

There are no records which indicate exactiy when the city's first poorhouse was built but it is known that a combined Poor and Workhouse was in operation as early as 1832. The Louisville City Directory, 1832, lists this institution

9

Ib1d., Section 7, pp. 54-56. 
as being located between Chestnut and Main and between 9 th and 10 th.

The City of Louisville's charter of 1851 contained considerable legislation concerning the Almshouse. An ordinance of this Charter, provided for many important changes in administration and financial management and specifically included provisions for more adequate medical care for the residents in the Almshouse. It established a Board of Guardlans, consisting of five members who were elected by the General Council and held their offices for two years and or until their successors were elected. The members of the Board had to be residents of the city and could not be members of the General Counc1l. The Board was empowered to elect a pres1dent and a secretary from its membership and prescribe the duties of each.

The custody and guardianship of the Louisville City Almshouse, its grounds and property and 1ts inmates were duly olaced under the Board. The Almshouse, offlcers and inmates were governed by rules adopted by the Board, subject to the approval of the General Council.

\section{0}

Revised Ordinances, City of Louisville, Charter of 1851, (Loulsvilie: W. N. Holdemen Co., 1854) Ordinance Number 202, Section 3, p. 163.

11

Ib1d., Ordinance Number 202, Section 3, p. 163. 
Specific instructions regarding the financlal management of the institution were included in the ordinance. It was made mandatory that the Board report once monthly to the General Councll upon the past transitions of the Board, the history of the institution and concerning the future needs of the Almshouse. Following these reports the General Council could appropriate any necessary funds as required, payable to the President of the Board of Guardians.

The Board was Iimited in its expenditures to the amount 13 of money appropriated by the General Counc1l. It was required to have all of its transactions recorded in a "well bound book" which was to be open for inspection by the Mayor or the General Council at all times.

In addition to the Board of Guardlans, the charter provided for the election of a Keeper of the Almshouse. The General Counc1l was empowered to elect one person as keeper for a period of one year and to set his duties and the amount of pay. The Keeper had to be a qualified voter of the city and must have resided in Louisville for at least one year preceding his election.

12

Ibid., Section 4.

13 Ib1d., Section 8.

14 Ibid., Section 4. 15 Ibid., Article 4, Section 9, pp. I7 f. 
The importance of medical care was recognized and the charter made it mandatory that "all needful nurses and attendants for the Almshouse" be provided for by the General Council. The medical care of the Almshouse was conferred upon the elected physician of the Western District of the City, who was to treat all indigent residents free of charge. 17 The physician was required to visit the institution at least once a day or as much oftener as the condition of the inmates required. He was also subject to call at any time, day or night, if this was deemed necessary by the Keeper. The doctor was to prescribe for the sick, see that the nurses performed their duties and that the patients were adequately cared for. The patients and all other poor persons were to receive medical care by the physician free of charge.

The Charter of 1851 also gave the General Counc1l permission to acquire and hold lands and erect buildings for an Almshouse within the limits of the city or in Jefferson 19 County. Finally, permission was given to levy and collect

16

Ib1d., Ordinance Number 202, Section 11, 0.18. 17

Ib1d., Article 5, Section 8, p. 47.

18

Ibid., Ordinance No. 186, p. 154.

19

Ibid., p. 47. 
an ad valorem tax not exceeding one dollar on each one hundred dollars' worth of property including a tax not exceeding five cents on each one hundred dollars for the support of the poor. 20 The Charter of 1851 made many noticeable advances. First and foremost, the Workhouse and Almshouse were separated and the immediate management of each institution was delegated to a single person. A lay group was appointed to serve as a Board of Guardians. Subsequent events proved that this Board did not function as expected, probably because of a lack of interest or because of the failure of the General Council to elect persons qualified to supervise the operation of the institution. Nevertheless, the control and management of the institution were definitely delegated to a given body despite the fact that the General Council retained the right of electing a Keeper for the Almshouse. It is difficult to comprehend why the keeper was to be elected for a period of only one year. However, there was no restriction concerning the number of years a single keeper might be appointed.

Provision for at least simple financial control was set up. Again, the requirement for allocating funds directly to the President of the Board of Guardians does not seem wise. The Board of Guardians was I1mited in its expenditures to the amount appropriated by the General Council. However, there was no evidence as to financial planning and funds were apparently aporopriated as needed. Probably the most outstanding

20

Ibid., ‥ 44. 
section of the Charter is the one dealing with medical care. A physician, nurses and attendants were provided for and their duties were clearly stated.

The Board of Guardians was apparently appointed in 1851 and the first new legislation following their appointment was enacted in Januery, 1852. By virtue of this law, the Board was authorized to bind out as apprentices to some trade or calling any or all male children unt1l they were 21 years of age and female children until they were 18 who were receiving public support in the Almshouse. Parents or friends who had permitted these children to become dependent upon the public were not permitted to interfere in any instance when the Board decided to bind out a child. There are no records which indicate the number of children affected by this act. However the Act does indicate that there was a considerable number of children in the institution at that time. The Act also clearly 1llustrates the philosophy of that date in the placing of responsibility for poverty upon the individual.

The fact that an ordinance was passed in 1856 replacing the Board of Guardians with a Board of Trustees tends to indicate that the Board of Guardians plen of management proved unsatisfactory.

21

Oliver H. Stratton and John M. Vaughan, op. c1t., p. 131. 22

Ib1d., op. $131 \mathrm{f}$. 
Under this Ordinance, the General Council was directed to elect in May of each year for a term of one year, three Trustees of the Loulsville City Almshouse. Two of the Trustees were to be members of the Board of Common Counc1l and the third Trustee was to be a member of the Board of Aldermen. 23

The Board of Trustees was to have responsibility for the supervision and control of the institution. It was required that the Board visit the Almshouse at least once monthly and that it report in writing monthly to the General Vouncil regarding their findings and recommendations.

At the first meeting of the council after the 9 th of March of each year, the Trustees were required to oresent a detalled report of all expenditures, its inmates received, discharged, deceased, and remaining in the institution. A statement regarding the management and condition was to be included. The Trugtees were also to present a statement showing financial receipts and an estimate of all expenditures for the succeeding fiscel year.

closely allied with this latter financlal provision, an ordinance was passed in the same year requiring that the Superintendent of the Almshouse make a monthly report of the full and entire expenses of his institution, together with a

23

The General Council was the legislative body for the city of Louisvile. It consisted of a Boerd of Common Council and a Board of Aldermen. 
report of all salaries of officers then due, together with all bilis created.

These laws were important for several reasons. F1rst of all, responsibility for pollcy making and management were placed in the elected officials, rather than having this power delegated by the General Council to another group. The first attemot at planning was made in that the Board of Trustees was required to submit a budget for 1 ts estimated needs for the coming year. More rigid control and accounting of funds were demanded. It was necessary that records and statistics concerning the residents be kept. Finally, the superintendent was given the responsibility for carrying out the policies of the Trustees and was also held accountable for a financial report.

At least one other city institution, The House of Refuge, was bullt during this period. Its aim, as expressed in the preamble of the Act passed by the Kentucky legislature in March, 1854, was "to prevent youth from becoming adeot in crime and subjects for the penitentiary." 25 The first youth was committed to the House of Refuge in July, 1865. By 1866 there were 135 boys and one girl living in the institution.

24

Oliver H. Stratton and John M. Vaughan, op. c1t., p. 132. 25

Memorial History of Louisville, edited by J. Stoddard Johnston, (Chicago: Amerlcan Biograohical Publishing Co., 1896) p. 342 . 
A third charter for the City of Louisville was adopted by the General Assembly of the Commonwealth of Kentucky on March 3, 1870, and this charter authorized the creation of a Board of Public Charities for the city. This Board consisted of the Mayor and six representative c1tizens elected by the General Council of the city for three year terms without pay. The Board was given control of the Loulsville Marine Hospital, the Almshouse, the Pest House (for persons suffering with contagious diseases), the Workhouse and the Loulsville House of Refuge for Females. Power to employ staff and $f i x$ salaries was vested in the Board. The first meeting of this new body was held In April, 1870. This Board introduced the centralization of administrative responsibility for the several city institutions in a single group and was the forerunner of our present Department of Public Welfare.

The final legislation enacted during this period was the passage of an act by the state Legislature in February, 1872, authorizing the Loulsville General Counc1l to 1ssue bonds, not to exceed $\$ 200,000$, for the purpose of building an almshouse, workhouse and pesthouse. Later in the same

27

Nargaret K. Strong, "Public Welfare Administration in Louisville, Ky." (Unpublished pamphlet, Un1versity of Louisville, March 20, 1935) pp. $12 \mathrm{f}$.

28 Memorial History of Louisville, op. cit., p. 342. 
year a tract of 200 acres was purchased and the actual erection of the present building was begun. This buildIng was completed in 1874 at a cost of $\$ 169,458.19$ and was occupled late in that year.

In the approximately forty years from the time of the opening of the original Home for the Aged to 1872, much legislation was enacted directly affecting the institution. Following the enabling legislation, necessary to permit establishment of the institution, most of the attention was directed toward administrative problems. The original combined Poor and Workhouse was separated Into two distinct institutions. The Charter of 1851 led to the creation of a Board of Guardians and placed administrative authority within this body. Financial management and medical care were also the subject of legislation included in this charter.

The Board of Guardians was soon replaced with a Board of Trustees. Monthly and annual reports were required. More rigid financial control was set up. In 1870 the Board of PubIic Charities superceded the Board of Trustees and several kindred institutions were placed under the supervision of a single body. This frequent change in the administrative set-up may indicate that the local governmental authorities were dissatisfied with the form of administration and that chenges were made to improve the administration of the 
1nstitution. It is possible, however, that the officials were anxious to retain political control of the Home and that the changes made were the result of their efforts to insure this continued source of political appointments. 


\section{B. 1873 THROUGH 1941}

As might be expected, the legislation enacted after 1874, when the present building was erected, was concerned primarily with changes in administration. The Board of Charities was replaced by a Board of Public Safety in 29 1893 and in 1930 the Home was olaced under the suoervision of the Department of Public Welfare.

The Board of Public Safety resembled its predecessor in many respects. The Board of Public Charities consisting of six members and the Meyor was appointed by the Generel Counc1l. The Board of Public Safety included only three persons, appointed by the mayor, and this body was given comolete control of all charitable, reformatory and penal institutions administered by the city, including the Home for the Aged, the City Hospital, the Workhouse and the Loufsville Industrial School of Reform. 31

The City Government Act of 1926 provided for the creation of a Department of Public Welfere and this Department was placed into operation on January, 1930. The Act indicated that the Department was to be under the supervision

29

Margaret K. Strong, oo. c1t., op. $14 \mathrm{f}$. 30

Ib1d., p. 16.

31

Ibid., po. $14 \mathrm{f}$. 
and direction of a Director of Welfare.

The Department was given exclusive control of all matters relating to the provision for the supervision of the care of adult and juvenile delinquents, dependents and the mentally deficlent. The Department was directed to invest1gate conditions contributing to dependency, delinquency and mental deficiency, to educate the public regarding these conditions and to adopt remedial measures. The supervision of public baths, comfort stations, cemeteries, the Detention Home, the Home for the Aged and Inf1rm and the Workhouse was delegated to the Department of Public Welfare. The provision for and supervision of public amusements and the oromotion of healthful recreation in playgrounds and community centers were specifically included in the Act. In order to provide trained workers for the Department, a section of the law permitted the supervision of the maintenance of classes in social welfare at the University of Louisville. Finally, the Director was given power to organize his department into such administrative divisions as might be necessary for the proper operation of the Department and also power to apooint the heads of these divisions.

This Act made many significant changes. Probably most important, administrative control and responsibility were

32

Ib1d., pp. 14-18 
placed on a single individual and he was given freedom to operate h1s Department as he desired. Since the Director was apoointed by and responsible to the Mayor, there could be no evasion of responsibility. In at least one instance, the Director of Welfare has been removed following public agitation for his aismissal.

For the first time, the administration of the Home for the Aged and Infirm and the Clty Hospital were separated and supervision of these two agencies vested in two separate departments. The Clty Hospltal was placed under the control of the Department of Health.

Other important innovations introduced by the Act were the provisions for a recreation program, an expressed interest in professional training, and the education of the community regarding existing conditions. The Division of Recreation was given decided impetus since the first Director of Welfare had had considerable experience in the group work field. A 1942 law, however, has transferred this division from the Welfare Department to a newly created department.

33

This occurred in May, 1940, when Director Solon F. Russell was discharged by Mayor Joseph D. Scholtz. 
CHAPTER III

ADMINISTRATION 


\section{ADMINISTRATION}

\section{A. 1832 to 1930}

Although it has not been possible to determine exactly when the city's first almshouse was erected, it is known that a combined Poor and Workhouse was in operation as early as 1 1832. Since the Charter of 1828 authorized the c1ty to build an institution of this type, it seems possible that several years may have elapsed before the institution was actually opened.

The Charter of 1828 provided that the Poor and Workhouse should be operated by a committee or Board of Counc1lmen or special overseers of the poor. No record could be located which indicated that special overseers were ever appointed and it appears likely that a committee of the Board of Councilmen assumed supervisory control, delegating authority to a superintendent or keeper.

The 1832 directory listed $M r$. J. C. Evans as keeper 3

of the Poor House. The 1836 Loulsville Clty Directory indicates that the Almshouse was located between 7th and 8th

\section{1}

Louisville City Directory, (Loulsville: Richard W. Otis, 1832$),$ p. 144 .

2

See Chapter of Legislation for information regarding Charter of 1828.

3

Louisville City Directory, 1832, p. 144. 
on Chestnut and that Mr. James Martin was the keeper. 567

The 1838-39, 1841 and the 1843-44 Directories place the Alms and Workhouse on Chestnut between 8 th and 9 th and Mr. Martin is again given as keeper. Although the institution is referred to as both the Almshouse and the Poor and Work House, the airectories probably refer to the same institution. The difference in location as given in the various directories may indicate that the quarters were unsatisfactory and that the institution was frequently moved.

The information secured is too scant for any adequate picture of the original institution. However, the frequent change in adaress might have been because the building did not meet the constantly increasing needs. In 1846 the city purchased the Cave Hill Farm and a new combined Poor and Workhouse was apparently constructed on that site. This arrangement continued until 1851 when the Poor and Work

4

G. Collins, Louisville Directory, (Louisville: Prentice and Welssinger, 1836) p. 11 .

5

G. Colilns, Louisville Directory, (Louisville: J. B. Marshall, $1 8 3 9 \longdiv { \text { D. } 2 6 . }$

6 G. ColIIns, Louisville Directory, (Louisville: Henkle Logan and Co., 1841) ○. 14.

7

G. Collins, Louisville Directory, (Loulsville: A. S. Tilden, 1843) D. 17 . 
Houses were separated.

The Charter of 1851 marked the first real effort at enacting legislation specially affecting the Loulsville City Almshouse, as it was termed in the Charter. A Board of Guardlans was created and its duties were specified. The Board was given power to control the activities of the institution but the General Council was given authority to apooint the keeper, who was responsible for actual supervision. The General Council was also to confer the medical care of the Almshouse upon the Physician of the Western District. Mr. Thomas Rush was aoparently the first person to serve as keeper of the Almshouse following the approval of the Charter of 1851. As far as can be ascertained, the Board of Guardians plan of management apparently did not prove satisfactory and in 1856 was replaced by a Board of Trustees. The membership of this new Board was to come from the Board of Common Council and the Board of Aldermen, whereas the membership of the Board of Guardians could not be made up of Counc1l members.

The Board of Trustees was required to report monthly to the General Council concerning its findings and recommendations and was also required to submit an annual reoort listing all expenditures and giving statistics concerning the number of admissions, discharges and deaths during the year. The

8 Charter of 1851 .

See Chapter on Leglslation for information regarding: 9 See Chapter on Legislation. 
Annual Report of the Trustees of the Almshouse for the year ending March 10, 1857, is apparently the first annual report made by that body. As far as can be determined this report was the first of its kind issued by any governing body of the institution. Since this report reveals considerable important data concerning the Almshouse, it seems advisable to quote from It at length.

The orlginal Board of Trustees had Joseph T. Burton, D. T. Monsarrat and Andrew Monroe as 1 ts members. The report of these trustees was as follows:

In the early part of the present session of the General Council, it was deemed necessary to the good management and usefulness of the Almshouse to abollsh the Board of Guardians, who exercised in years past the control of the same, and elect in lieu thereof three Trustees, composed of members of the General Council. The Trustees entered uoon their duties in the early part of June last, a short time after the election of the present efficient and energetic Superintendent. The first object of the Trustees was to bring about a reform in the management of the Institution and, if oossible, to introduce a system of discipline and economy thet would eventually prove a benefit to that class of persons who seek a home there, as well as to save the city a considerable expense and unnecessary outlay for the support of its paupers. The trustees found that there was an unnecessary number of officers and their families in the Institution, supported at public expense, whose service could be disoensed with, without in any way affecting its prosperity; and as the present superintendent is a physician, he was able to discharge the duties of apothecary, male nurse and guardian, thereby saving their respective salaries and the expense of supoorting

\section{0}

Annual Report of the Trustees of the Almshouse of the City of Loulsville for the year ending March 10, 1857, (Louisville: Hull and Brother, 1857) 
their families.

The inmates of the Institution, at the time we entered upon the discharge of our dutieg, were disinclined to labor, having been permitted heretofore to spend their time in idleness and inertness for months and in some instances for years past, without being aroused to a sense of their ability to do some character of work that might compensate the city for taking care of them. The superintendent was directed to bring into requisition all the labor he could consistently do, in order that the dormant energies of the inmates might be stimulated. He discharged this duty with the most salutory and beneficial effects to the inmates, who in many instances became satisfied that it was only necessary to exert themselves and there would be no occesion for their longer dependence upon charity for an honest support. This resulted in inducing a number of inmates to leave the Almshouse and seek employment elsewhere, which they did with a great improvement in their moral and physical condition.

We annex the report of the superintendent and by an examination of the expenditures incurred in support of the Almshouse during the past year, it $W 11$ be seen that the amount expended is scarcely one half that of the oreceding year; and the Trustees are satisfied that if it had not been for the severe drought of last year and the severity of the past winter, the expenditures would have been much less.

The inmates are all cheerful and well provided for.

The Trustees, in view of the economy exercised in this Institution, the necessity for the comfort and convenience of the officers and inmates, and the present incomplete conditions of the Institution, recommend that an additional aporopriation be made to that head, the condition of the finances of the city will admit of 1 .

The superintendent's rebort elaborates on the data revealed in the reoort of the Trustees and affords much insight 
a.s to the policies in effect as well as the thinking of the head of the Almshouse. Dr. Joseoh W. Putman served as Superintendent during the year the report covered and his report, In part, is as follows:

In our management of the inmates of this Inst1tution, it has been our aim in the first place to see that they were properly orovided for, in everything that it was essential for them to have as paupers and so far as possible, pald strict attention to their condition in point of cleanliness. We also made it compulsory that all should work, so far as their ability enabled them to perform that duty, which we conceived to be of great imoortance with the class of people that generaily inhabited the Almshouse. In strict observance of this rule, many of the inmates experienced considerable inconvenience and.... did exoress great dissatisfaction....at present there is far less difficulty in enforcing this regulation. A considerable inconvenience is caused by not having any regular emoloyment and more esoecially at times in not being able to find work for one third of those who are able to perform some character of labor..... the only labor lisely to be oroductive.... is that belonging to the agricultural oursuits... The great mass of inmetes are peculiarly dull and inefficient.

No olan could be adootea, more likely to fulfili the object to be desired than that of associeting the Almshouse and House of Refuge under the same management and control.

The present condition of the Almshouse, we should regerd as quite favorable. It has been our effort not only to keeo uo repairs but to make such imorovements as were essential.

The health of the Institution for the past year has been oarticularly good. There has been no epidemic.

We have had no school, and consequently, no teacher. In fact, there wes but one child in the Almshouse caoable of receiving instruction, 
until within a very brief period; the rest of the children being elther too young or mentally incapacitated to receive any information from such a source. We shall open a school on April lst, abolishing pay officers. I feel satisfied that there can always be procured some of the inmates fully competent to discharge the duties of teacher, so far as may be required for Almshouse purooses, thereby saving a considerable expense to the Institution.

In evaluating the policies of the Board of Trustees and the superintendent, it is essential that the prevalling social philosophy of their time be considered. We have already mentioned that much of our sociol thinking was taken bodily from England. The English Poor Law of 1601 was the source of the orinciples of local responsibility, the reauirement of legal residence and the responsibility of relatives for financial assistance. The British Royal Commission of 1834 formulated the 1 dea of deterrence in the treatment of poverty. The Commission desired to make relief unattractive. The lot of the needy was to be made worse than that of the lowest paid independent worker, that is, relief standards were to be lower than the amount of pay the lowest paid worker might earm. The person in need was also forced to submit to a workhouse test as proof of his desire for emoloyment. Any person refusing emoloyment at the workhouse would be ineligible for any type of assistance.

Deterrence, therefore, was the predominating policy of the day. Legal residence in some instances as much as ten years, had to be fully established and the reciolent of 
assistance had to work for his own benefit and the benefit of the institution. The first object of the Board of Trustees was to bring about a change in management and to lower the cost of operation. The superintendent was directed to "stimulate the dormant energies of the inmates" by forcing them to work. As a result, many were "induced" to seek emoloyment elsewhere, which they did with "a great improvement in their moral and ohysical condition." As a result of this program, the cost of operation drooped over fifty per cent in a single year.

This statement represents, of course, only the expressed opinion of the superintendent and there is no evidence that any follow uo was ever made by him to lend credence to the statement. The statistics given, however, do indicate that the cost of operation was lowered over fifty per cent in a single year.

The superintendent considered the residents as being dull, inefficient and best suited for agricultural labor. $\mathrm{He}$, too, felt that it was imperative that all work, although there was no suitable employment for fully one third of those able to do some tyoe of work. Dissatisfaction regarding this enforced employment was "oroperly handled," but no information is given concerning what methods were utilized to overcome such dissatisfaction.

The total picture secured is one of stern discipline with a constant drive for increased economy. A great many 
persons were admitted during the year, but a larger number was discharged. Meny children Iived at the Institution and at least elght were born there during the year. There was no segregation of the sexes. Since slavery was still the order of the day, there were no colored residents.

The first institution established following the charter of 1851 was probably erected between 29 th and 3Ist streets and between Alford and Duncan streets. Th1s Iocation is given for the old Almshouse on a map of the Clty of Louisville, drawn by the City Engineer in January, 1873. This location was in the northwestern part of the city and would normally have been within the boundary cared for by the Physician of the Western District. Although the Annual Report for 1874 states that the Almshouse was located on Chestnut Street, between Floyd and Preston, this reoort also lists the City Hospital at the same location, and it is believed that this was a tyoographical error.

No Annual Reports could be found for the nerlod between 1857 and 1866 and no data concerning the Almshouse for the period is avallable. However, it is known the clty itself continued to grow and this increase in population again resulted in an effort on the pert of the city government to meet the needs of the community. The clty's popuIation, which totalled 43,217 in 1850 , rose to 68,033 in 1860 and by 1870 this figure had mounted to 100,753 .

11

History of Ohio Falls Cities and Counties, 1778-1882, (Cleveland, Ohio: L. A. Williams and Co., 1886), Vol. I, o. 88. 
The Civil War found Loulsville, the same as Kentucky, divided in 1ts stand. Theoretically neutral, many Loulsvilizans saw active service in the opoosing armies. After the war, however, the city faced a hitherto unknown oroblem, thet of the emancloated Negro.

A new city cherter was adopted by the General Assembly of the state on Mrrch 3, 1870, and the creation of a Board of Publ1c Charities differed from its oredecessors in thet its influence was not limited to the operation of the Almshouse but that several sinilar institutions were also olaced under its control. These included, in addition to the Almshouse, the Louisville Merine Hospital, the Pest House, the Vorkhouse and the Loussille House of Refuge for Females. All of these institutions may well have been closely associated with the Almshouse. It is known that many hospital patients were later admitted to the Almshouse and this may also have been true of the Pest House. The Workhouse has long been a source of admissions to the Almshouse and may have been so in 1870. In view of the presence of chilaren In the Almshouse, it is quite possible that some of these might have been transferred to the Lovisville House of Refuge for Females. It is also quite probable that any surolus food raised at the Almshouse was sent to the other institutions.

The Board of Public Charities immediately directed 
Its attention toward the need for a new bullaing and stressed 12

this need. In discussing its reasons for desiring a new

building, the Board made the following statement:

The Almshouse should be arranged with due consideration of the health and comfort of its unfortunate inmetes, but its arrangement and olace should not be inviting to those who are able but too indolent to work; sufficient land. should be obtained to emoloy all of the inmates who are able to do farm work and suitable shops and rooms should be furnished where those who are unable to do outside work or can be more orofitably emoloyed can be, as fer as oracticable, keot at work of some kind so that every one who, on examination, is pronounced sufficiently able bodied, may be compelled to work for their board and support, not with the idea of making such an institution a source of profit to the city, but to make it as nearly self sustaining as possible. Almshouses have always been difficult problems in all crowded communities and care, attention and experience alone will enable us even partially to solve ours. 13

This statement afforis some insight as to the thinking of the Board. Although the Board recommended that the new bulling should be arranged with consideration of the health and comfort of the residents, the Board warned against making it too inviting so that it would not prove attractive to those who were unwilling to work. The Board also felt that everyone

12

Louisville, $\mathrm{Ky}$, Municipal Reports for the Fiscal Year Ending December 31, 1870, (Louisville: Bradley and G11bert, 1877), p. 288 .

13

Ibld., pp. $288 \mathrm{f}$. 
who was able should work for his support and recommended an extensive worix program. Deterrence was apparently still a major emphasis.

The post-Civil War oanic plus a large increase of "non-resident paupers" Ied to the establishment of the first known admission policy by the Board of Public Charities. In 1875, this Board ruled that admission to the institution would be limited to those who had resided in Loulsville for at least twelve months prior to the date of admission and that future admissions could be made only by members of the 14

Board. The requirement of residence was quite common and in no way unusual. However, the restriction of the right to admission to the members of the Board would tend to indicate that prior to 1875 admissions might have been made et the request of any influential citizen.

Several efforts were made by suoerintendents to establish schools for children residing in the institution. In 1876 a school was organized and thirty-s1x pupils, presumably children, received instruction from one of the res15 idents. The number of oupils dropped to only five during

14 Book, p. 1 .

Loulsville Department of Public Welfare, Policy 15 Ibid. 
16

the next year. There was apparently no school between 1878 and 1881 , when another class was organized. No records could be found which would indicate whether any further efforts were made to provide educational facllities for the residents. However, since the Board of Public Charities began refusing admission to children in 1886, it is quite probable that the 1881 class was the last one organized. As far as could be determined, regular church services 18

were first inaugurated in 1876. This practice has continued down to the present time and at the close of 1941 many church groups were visiting the institution regularly and services were being conducted regularly.

In 1885 there was agitation for the removal of children from the institution. On March 10, 1885, the Board pointed out that there were some forty or fifty boys in the almshouse "who have no business there." It was sugeested that they might be bound out or that they might be committed to the House of Refuge, where they could earn a living and at the same time learn trades which would be useful to them

\section{6}

Loulsville Municioal Reoorts for the Fiscal Year Ending December 31, 1877, (Loulsvilie: John P. Morton and Co., 1878), 0. 562 .

17

Louisville Munic1oal Reports, December 31, 1881, (Louisville: Gilbert and Mallory Publishing Co., 1882), p. 316.

18

Louisville Municioal Reports, December 31, 1876, (Louisvilie: Hull and Brother, 1877), p. 570. 
in the future. In 1886 the Board adopted the policy of refusing admission of children to the Almshouse.

The Board of Public Charities was replaced by a Board of Public Safety in 1893. The new Board resembled its predecessor in many respects and the chief difference apoarently was that the new Board consisted of only three members. The Board of Public Safety was given jurisdiction over the city's 20 charitable, reformatory and penal institutions.

The name of the institution was officially changed in 1895 from the Loulsville City Almshouse to the Home for the 21

Aged and Infirm. Desoite this change, the institution continued to appear in print frequently as the Almshouse and the sign appearing at the entrance to the grounds continued to be the "Almshouse" unt11 about 1935.

The register maintained at the Home from 1910 to 1930 reveals a slight amount of data regarding record keeping at the institution during that period. The name of the residents were listed alphabetically and each resident was given a line in the book. The following information was listed

19

Louisville Commercial, March 11, 1885. 20

Margaret K. Strong, op. cit., p. 16. 21

Louisville Municloel Reoorts for the Fiscal Year Ending August 31, 1895, Louisville: Courler Journal Job Printing Co., 1896), o. 857 . 
concerning each resident: name, age, color, sex, date of admission, source of admisgion, nativity, relatives or friends, date of discharge, disease, and remarks. The entries are brief and were apparently hurriedly written. There are two "blackl1sts" one dated 1914 and other dated 1924, Iisting persons who were to be refused readmittance to the Home.

An article apoearing in the Louloville Courier Journal on October 15, 1916, stated that the Home was being operated in a very efficient manner. Mr. F. H. Bundschu, superintendent, had taken measures to greatly increase the productivity of the farm and had also introduced the canning of farm products, thereby saving the city about 1000 annualiy .

Mr. George Mayberry became superintendent in November, 1919, and 1mmedietely took steps to remove many residents from the institution. Mr. Mayberry took a census of the Home populetion and found that many of the residents had parents or children financlally able to care for them. He compelled these relatives either to furnish a home for them or to pay for their support. 23 since no statistics could be found which would indicate how many persons actually left

22

Loulsville Courier Journal, October 15, 1916. 23 Louisville Courier Journal, April 3, 1919. 
the institution as a result of this program, we have no way of knowling whether the number of residents was actually lowered.

There are indications that the superintendent's position, orior to April 1, 1938, was always a political job awarded on the basis of party service. The Annual Reports reveal almost invariably a change in superintendents following each election. On several occasions the same person has retained the position for a number of years while the same party remained in office. For example, George Mayberry was superintendent from November, 1919, until July, 1927, when he lost his job because of a political turnover. However his party, the Republican, came back into office later in the same year and on December 1, 1927, Mr. Mayberry again became superintendent. He retained this post until May, 1930, when he resigned because of 111 health.

Mayor William B. Harrison, in December, 1927, 1ssued a statement in which he promised that the Home would be removed from politics. He stated that he had been informed that an aged Negro woman had been "thrown out" because of her refusal to vote the Democratic ticket. It should be pointed out that the Democratic Party was in office only from July, 1927, to November of that year and that $\mathrm{Mr}$. Harrison was a nember of the Republican Party.

24

Loulsvilie Courier Joumal, December 1, 1927. 
On January 1, 1930, the Department of Public Welfare was olaced in operation and assumed control over the Home for the Aged and Infirm. The institution has continued as a division of this Department down to the present time. The administrators of the Home from the time of its establishment until 1930 were interested in several factors. First of all, attention was apparently devoted to operating the institution at as low a cost as possible. This conclusion has been drawn from the continued emphasis on the cost of operation and the superintendents were apoarently constantly striving to lower the per diem cost. On at least one occasion, a superintendent pointed out that the per diem cost was probably the lowest of any similar institution in the country. Closely allied with this was the effort to increase the productivity of the farm. The Annual Reports constantly stress the efforts of the superintendents in this regard. Much interest was displayed in the attemots of the various Boards and Superintendents to limit the number of admissions. This was done through a pollcy of deterrence and a deliberate effort to refrain from making the institution too attractive, thereby discouraging applications for admission.

On the favorable side, the aoministrators apoarently strove to improve the physicel plant and constant improvements were made. Much interest was also shown in the physical well

\section{5}

Louisville Municipal Reoorts for Fiscal Year Ending August 31 , 1895, (Loulsville: Courler Journal Job Printing Co., $1896)$, o. 857 . 
being of the residents and medical care was apoarently on a fairly high level, all things being considered.

In the final analysis, however, it seems that the cost of operation was given the first attention and the welfare of the residents was given only secondary consideration. 


\section{B. 1930 THROUGH 1941}

The period between 1930 and 1941 brought many important administrative changes to the Home for the Aged and Infirm. On January 1,1930 , the newly created Department of Public Welfare assumed control over the institution and shortly thereafter assumed responsibility for admissions to the Home. A social worker was attached to the institution for the first time and a social worker has continued as an imoortant unit of the Home's personnel. In 1935 the superintendent was relieved of responsibility for operating the Home farm. The establishment of a public relief agency by the Department of Public Welfare, and the assumption by this agency of the responsibility for admissions to the Home was an imoortant step forward. Finally, the inauguration of the Old. Age Assistance program in 1936 has had some effect on the Home, though not nearly as great as had been hoped.

Mr. Fay Marvin became the first director of the newly organized Department of Publ1c Welfare on January $1,1930$. One of Mr. Marvin's first acts was to apooint a social worker to the institution to take charge of admissions. This worker made a survey of the Home's population and found thet the average age of the residents was 68 .

26

Reoort of City of Louisville Comotroller and Inspector, (Louisvilie: February 17, 1931), 0. 2 . 
Mr. Mayberry, the superintendent, and Mrs. Mayberry, the matron, resigned on May 9, 1930, as Mr. Mayberry felt that he was too old to continue in his capacity. The fact that the Home had received some unfavorable criticism regerding the food at the institution may have influenced Mr. Mayberry's decision.

On August 1, 1930, Cantain Taylor Gray and Mrs. Gray assumed the position of suoerintendent and matron, respect1vely. Conscious of the criticism concerning the alleged poor quality of food being served, Captain Gray made an effort to improve the quality and veriety of the food. In August, 1930, the staff consisted of a social worker, a laundress, a seamstress, flve nurses, a supervisor of nurses, and a bookkeeoer, in adition to Captain and Mrs. Gray.

Following the trend established in many cities throughout the country, the city, in 1930, subsidized the orivate family agency to cope with the serious relief oroblem. The Family Service Organization was given $\$ 18,211.35$ in the fall of 1930 for relief expenditures while the Deoartment of PubIic Welfare assumed responsibility for admissions to the Home

27

Louisvilie Times, Moy 9, 1930.

28

Louisville Herald Post, August 24, 1930. 29

Ibla. 
and also distributed coal orders.

In November, 1930, the city opened an Unemployment Relief Bureau and this was succeeded by the Municlpal Relief Bureau in 1931. Since 1931, that agency and 1ts successor, the Municloal Bureau of Social Service, has had charge of admissions to the Home. In the Annual Report of the Department of Public Welfare for the fiscal year ending August 31, 1932 , one section of the report of the Municioal Relief Bureau deals with the care of the aged. Since this section is directly concerned with the Home and as it is indicative of the policies then in effect, it seems advisable to quote from it at length:

Practically since the opening of the Bureau in November, 1930, it has had to assume the direct responsibility for the aged groun. Due to the economic depression the number of applicants has mounted during the past year until the social worker in charge of the work carried an average case load of 70 per month. Out of the large number of applicants, an average of 4 are admitted to the Home for the Aged and Infirm per month. The others are olanned for soclally. During predepression years - prior to making social investigations - an average of 12 admittances to the Home were made per month. Figuring uoon this basis the Bureau saves the City of Louisville more than $\$ 14,000.00$ per year by careful investigation.

Social planning enteils visits to relatives, friends, churches, fraternal organizations, etc., in an effort to plan for the apolicants outside of the Almshouse. Many do not aporove of their

\section{0}

Mildred E. Bateman, "Lay Participation in the Private Family Agency" (unoublished M.S.S.A. dissertation, Graduate Division of Social Administration, University of Loulsville, 1941), p. 150 . 
relatives being admitted to a charitable institution and prefer to assume the financial responsibility. Then, too, the client is more accustomed to home life and can be cared for more cheaply in a private home than in an institution. The social worker continues her contact with the client after he is admitted to the home in the hope to effect a proper adjustment there. 31

During the fiscal year there were 382 aoplicants for admission to the Home. Of this number, 57 were admitted to the Home and the remaining number was planned for outside the institution.

This statement indicates a complete change in social ohilosophy on the part of the city government and the adoption of a modern point of view in 1ts dealing with the aged. The emphasis for the first time was placed upon retaining the individual within the community rather than placing him in an institution and forgetting about him.

Mr. Fay Marvin resigned as Director of Welfare in May, 1933, and was reolaced by Mr. Thorton Wilcox. Mr. W1lcox served only a short time and was replaced by Dr. Kenneth $P$. Vinsel. Following the November, 1933, city election, Captain Gray was replaced as superintendent by Mr. Garner G. Denton,

31.

Annual Reoort of the Deoartment of Public Welfare, F1scal Year Ending August 31, 1932.

32

Ib1d.

33

Ibid.

34

Louisville Courier Journal, June 17, 1933. 
and in June, 1934, Dr. Macon C. V1ck, a minister, was ap35 pointed superintendent of the Home, a position which he held until December 15, 1941.

In september, 1935, the management of the Home's farm 36

was transferred to the City Workhouse. During the century of the Home's existence, the superintendents were forced to devote much of their time and energy toward making the farm productive and profitable. Since this in itself was a large task, (there were 225 acres under cultivation in 1931) it is difficult to see how the superintendent could devote much time to the welfare of the residents. Typical examples of this emohas1s on the farm may be pointed out by a statement mace by the suoerintendent, Caotain Gray, in 1931. Captain Gray stated that the most definite accomplishment at the Home during the 1930-31 fiscal year was that of making the farm and dairy self supporting. New livestock had been purchased and the acreage under cultivation had been increased.

With the inauguration of an 010 Age Assistance orogram in the fall of 1936, the Deoartment of Public Welfare began

35

Annual Report of the Deoartment of Public Welfare for the Year Ending August 31,1934 .

36

Ib1d.

37

Annual Report of the Department of Public Welfare for the Year Ending August 31, 1931. 
to exert pressure on the state Department of Welfare to assume responsibility for the care of the aged. Mr. Solon F. Russell, who had been apoointed Director of Welfare for the city in December, $193^{\%}$, pointed out that the greatest number of relief clients were the incapacitated, the aged, and mothers with dependent children, in the order named. Greater assistence by the state in the care of the aged through pensions was deemed urgent since the "city cannot continue indefinitely to care for persons eligible for old age pensions." 38

Fully one third ( 33 per cent) of those receiving financial assistance from the Municloal Bureau of Social Service durlng the 1936-37 fiscal year were classifled aged. In an apoarent effort to force the state to grant pensions to this group, direct relief was discontinued by the city on July 1 , 1938 to "anyone eligible for state and Federal subsidized assistance to the aged." The word "eligible" is important since it demonstrates that all of the aged group, regardless of the status of their applications for Old Age Assistance, were denied further financial assistance in their own homes.

The adoption of this policy, of course, had a direct effect uoon the Home. Prior to July, 1930, an effort was apparently made to induce as many of the aged group receiving assistance to acceot admittance to the Home. Statistics of

38

Ibid., 1937. 
the Municipal Bureau reveal that 33 cases were closed during the 1937-1938 fiscal year as the cllents were admitted to the Home. However, the Home's records for the same period indicate that 64 persons were admitted, so that the 33 clients listed by the Municioal Bureau were apparently persons who had been receiving assistance (as contrasted with clients applying solely for institutionalization) and who preferred to accept care in the Home to a complete cessation of financial assistance.

As a result of this drastic policy, the aged category receiving rellef dropped to only 13 per cent of the total relief load, a drop of 20 per cent in a single year. In July, 1938, alone, 117 cases were closed, the reduction being attr1buted directiy to the discontinuance of relief to aged persons eligible for Old Age Assistance.

The Debartment of Welfare continued its restrictive relief policy during the 1938-1939 fiscal year. During that year financial assistance to the aged was Iimited to those instances in which the head of the family was ineligible for Old Age Assistance even though over 65, and cases where the head of the family was receiving a pension but had other

39

Ib1d., 1938.

40

Ib1d., 1939, p. 23. 
dependents to support. 41 In 1938-1939 the aged relief group made up only 4.2 per cent of the total relief group, a drop of 28.8 per cent in two years. The effect the pollcy had had on the number of admissions to the Home may be gained from the following table.

$\begin{array}{cc}\text { Fiscal Year } & \text { Number of Admissions } \\ 1936-1937 & 40 \\ 1937-1938 & 64 \\ 1938-1939 & 85 \\ 1939-1940 & 118 \\ 1940-1941 & 103\end{array}$

In addition to restricting financial assistance to the aged, and thus indirectly causing an increase in the number of residents admitted, the Municipal Bureau of Social Service, in its reoort for 1939-1940, also indicated a change in emphasis in its policies regarding admissions to the Home. The Municloal Bureau reoort contains the following statement:

Although admissions to the Home for Aged and Infirm in the past were based solely on age and indigency, during this year a new use for the Home became apoorent. In analyzing the "single" case load of the Municipal Bureau of Social Service (which constituted 40 per cent of the entire load), it was found that 4 per cent of these individuals were bedfast, while another 31 per cent were chronically ill and in need of care not available to them in their own home. A number of single cases currently referred to the Bureau required medical care, special diets and bed rest, and it was possible for the agency to supoly this specialized care at the Home for the Aged at a limited cost.

41

Ibid.

42

This material has been collected from the Department of Public Welfare Annual Reports, 1937 through 1941. 
Arrangements were made to care for all bed patients, the very feeble and those requiring institutional care at the Home. 43

The use of the Institution as a hospltal for the chronically 11 was the result of a trend which had been increasingly pronounced since 1930. Avallable data indicated that the Home had long served in this dual capacity, 1.e., a home for the aged as well as a chronic hospital. In 1930 a clinic was opened for the residents. At that time there were only two hospital wards in the home, for white men and women only. During the entire period a constant effort has been mede to imorove the medical care for the residents by the addition of medical staff members and through the instalIation of medical equipment. By August, 1941, 28 per cent of the population was confined to bed because of chronic ill44 ness.

The administration of the Home has recelved considerable oublicity during the oast few years, and much of it has been unfavorable. Varlous Grand Jury reports have severely criticized the administration and the physical plant. These reoorts, however, have been inconsistent since one report may be extremely harsh while a similar report, issued a month later, may be highly favorable.

43

Ibid., 1941. 44 Ibid., See Chaoter on Medical Care. 
Most of these reports have criticized the physical plant and have recommended a new bullding. The January, 1935, Grend Jury charged management at the institution and soored the "filthy condition." Several reoorts criticlzed the quality of food being served and the lack of variety in the alet. As an example of the inconsistency of the reports, the May, 1935, Grand Jury commented unfavorably concerning the Home while the June, 1935, Grand Jury report was comolimentary. The November, 1935, Grand Jury report recommended a change in management at the institution, since its investigation had revealed intimidation of inmates, abuse of inmates by attendants, no efforts to punish such abuse, too much politics, too much favoritlsm, managerial ignorance of conditions, and wosting of funds. Mayor Neville Miller protested that the Grand Jury's charges were without foundation and that the Grand Jury had been motivated by oolitical interests. During 1939 and 1940 there were a series of allercations between the Director of Welfare, Solon F. Russell, and various members of the staff of the Home. On Anust 26, 1939, Mr. Russell made a surprise visit to the institution and was "amazed at the filthy condition." He reorimanded Dr. Vick, the superintendent, and suspended Mrs. Vick, the matron, as

45

Louisville Courier Jourmal, February 5, 1935. 46

Louisville Courier Journal, November $30,1935$. 
she was held responsible for the cleanliness of the insti47

tution.

A worker, sald to have been found sleepling, was discharged and Mrs. Vick later resigned.

On February 17, 1940, a utility man and a truck driver were dismissed as they were charged with convering gasoline belonging to the Home for their own use. ${ }^{48}$ on the next day Dr. Vick was suspended for fifteen days, as Mr. Russell

charged him with non-performance of duty and with permitting fighting among the employees.

Mrs. Brashear, a nurse, was discharged in March, 1940, and her subsequent apoeal to the Personnel Commission led to an investigation of the Home by that body. The Personnel Commission uphela the dismissal but issued the following statement (in part):

At times an aged inmate must have found it difficult even to enjoy death in peace. Malicious gosslping, talebearing, scandei-mongering and sordid inside oolitics have apparently consumed a large part of the time of certain employees and have resulted in serious impairment of the institutional work of the Home. 50

47

Louisville Times, August 26, 1939.

48

Louisville Courier Joumal, February 17, 1939.

49

Ibid., February 18, 1939.

50

Ib1d., May 3, 1939. 
The Commission believed that "a competent superintendent, vested with adequate authority, could correct this condition in a short time." 51

Beginning with 1930, a soclal worker has been attached to the Home for the Aged and Infirm. At the outget, this worker assumed responsibility for aporoving admissions to the Home, but this function was later taken over by the Municloal Bureau of Social Service.

The role of the social worker at the Home is described

In the Annual Report for 1937 by the following statement:

Under the suoervision of a trained social worker, the social service section now is responsible for both case work and recreation.

Working closely with the Municloal Bureau of Social Service and City Hosoital, the social worker handles all intake, personel interviews, visits to relatives of residents on specific problems, and preparation and maintenance of case histories of all residents. New and more complete admittance forms and filing systems have been introduced. Handlcraft, band and orchestra concerts, plcture shows, minstrels, marionette shows and card games are among the recreational activities.

The Louisville Free Public Library furnishes discarded books and magazines. A special room is used for the handicraft classes. The regular monthly entertainments are held in the new assembly room on the second floor. Birthday parties and small gifts are given each month for all residents having birthdays during the month. Many Loulsville churches of all denominations manifest an active interest in the institution.

51

Ibid. 
The new recreation room for Negroes has been of material ald in proviaing recreation facilities for that group. 52

Since the average population in 1941 was 236 and as there were 103 admissions during that year alone, it is evident that the social worker's task is extremely difficult. Following acceptance of an applicant by the Municipal Bureau of social service, the client is sent to the institution. The agency forwards to the Home an admittance summary which includes relevant deta regarding the client. It is then the task of the social worker to help the new resident in his a.justment to institutional 11fe. Case histories are kept a.s current as possible but this in 1tself is a huge task. Recreational activities must be organized, although the Recreation Department of the city assists with this program. Funeral arrangements and notification of relatives in instances of death also consume a large portion of the social worker's time.

Consider ng the vast amount of work to be done, it seems quite apoarent that the social worker does not have much time to spend in trying to arrange placements for the residents outside the institution. However, in 1941, the soclal worker, Mrs. Ellzabeth B. Glenn, initiated and oarticipated actively in a joint study made by a committee from the Municioal Bureau of Social Service, and the physician at

52

Annual Reoort of the Deoartment of Public Welfare, Flscal yeer Ending August 31, 1937 . 
the Home. Sixty nine residents who wished to be considered for Old Age Assistance were studied and recommendations concerning their future care were made. Th1s study is important since it affords an opportunity for making a survey of the Home's pooulation and since it may lead to future empha81 s on placement of residents outside the institution.

At the close of 194I, the Department of Public Welfare was seriously concerned with the increased need of the chron1cally ill for hospital facilities. During the year the number of bed patients at the Home had nearly doubled and it had been necessary to restrict admission of the more able bodied in order to give preference to those needing institutional and bedside care. Admissions to the Home were being governed by the individual's needs for institutional, custodial or nursing care. However, since the aged comprised only 6.1 per cent of the city's rellef load, 1t seems apparent that a restrictive pollcy concerning ald to the aged was still being followed.

53

Ib1d., 1941. 
GHAPTER IV

POPULATION 


\section{LEGISLATION}

\section{A. 1857 THROUGH 1941}

In discussing the make up of the population residing at the Home for the Aged and Infirm there are several factors which must be considered in relation to the institution. One of the most important of these factors is the availability of other resources, either specialized institutions or oubI1c assistance programs to cope with the problem. Another factor is the current social philosophy of the community, both from the point of view of theory and the actual practice.

When the first local Almshouse was opened there were apoarently few local institutions. These consisted of a hospital, founded in 1817, and possibly a county jail. A state Board of Health was organized in 1822. The first Home was a combined Poor and Workhouse, placed into ooeration about 1832. In view of the lack of other resources, the population of this original institution was undoubtedly comoosed of individuals of every age group and in every possible physical and mental condition. Since slavery was practiced in Kentucky, the negro did not present a problem in the early days of the institution's existence. The 1832 City Directory indicates that the institution housed the city's "poor and sick."

1

Material included in this Chaoter was secured orimarily from Annual Reoorts for the Home for the Aged and Infirm from 1857 to 1941 . 
No record could be located which would indicate the number of residents in 1832. However, the fact that the institution was moved frequently during its earlier years and the separation of the Poor and Workhouse in 1851 may be an indication that the size of the population was constantly increasing. It is known that the population of the city grew tremendously between 1830 and 1850 .

The Annual Report for the Year Ending March 1, 1857, contains statistics regarding the number of residents. The following table appears in the Annual Report:

Adults

Remaining on frarch 1,1856

Admitted

Discharged

Died

Remaining on March 1, 185 ?

Children

$\begin{array}{ll}\text { Remaining on March 1, } 1856 & 56 \\ \text { Admitted } & 63 \\ \text { Discharged } & 94 \\ \text { Died } & 11 \\ \text { Remaining on March 1, } 1857 & 15\end{array}$

These figures reveal thet al though the number of admissions was high, the number of discharges was even greater. Children made uo substantial portion of the entire grouo. According to the ohysician, eight children were born in the Institution during the year. Diseases treated included blindness, epllepsy, 1diocy, gonorrhea and secondary syphilis.

The number of residents continued to increase and new problems were encountered. In 1868 the first attemot of . segregation of the sexes was made when a fence was erected, 
both in the yards and in the bullding. In 1866 the Freedman's Bureau, which had been organized to care for the emancipated negro, ceased to operate and the c1ty found it necessary to admit negroes to the institution for the first time. In 1869 a building was erected for negroes and twenty negroes were admitted during that year. The number of negro residents has increased steadily and by 1941 comprised almost half of the total number.

Another difficulty encountered was the need for a new building. As early as 1867 the Board of Trustees recommended the erection of a new building and this was finally erected in 1874. The opening of the new building brought with it a marked increase in the number of residents. By 1876 there were 331 residents.

The movement in the latter half of the 19th century to remove certain groups from almshouses directly affected our own institution. This is oarticuiarly true in the movement to remove children from the almshouses. The first known children's institution in the city, the House of Refuge, was opened in July, 1865, and by 1866 there were 135 boys and one girl in the institution.

The number of children admitted to the Home annually ranged from a high of 63 in 1856 to a low of only 4 in 1888. No children under the age of ten were admitted after 1888. The Annual Report for the year ending August 31, 1886, indicated that there were no children remaining in the institution 
on that date and 1 is is probable that any children admitted during 1887 or 1888 were probably accepted only for temporary care. There is no information available which would indicate what plans were made for the children previously placed in the Almshouse. However, there are several possible alternatives which may have been used. The House of Refuge may have been used for caring for dependent children. The Board of Charity Commissioners in 1885 suggested committing the forty or fifty boys and girls in the Almshouse to the House of Refuge. Again no information has been found which would show that this was done nor can it be determined to what extent the dependent children were committed to the House of Refuge.

The Louisville Charity Organization Soc1ety, organlzed in 1883, may have taken steps to work out some plans for children. Finally, the city may have resorted to binding out children, since such legislation had been possed in 1852 by the city.

Following the elimination of children, the next emphasis was made in the direction of removing those persons under 20 from the institution. This goal was achieved by 1900 and w1th only few exceptions since that time have persons under 20 been acceoted for care at the Home.

The elimination of those persons under 20, of course, tended to raise the average age of the residents. In 1873 , 58 per cent of the resident population was less than fifty 
years of age. By 1880 , the pendulum had swung so that 59 per cent of the population was over 50 years old. W1th the elimination of children in 1886, the percentage of residents over 50 rose to 74 per cent. The number of persons between 20 and 50 increased between 1886 and 1900 so that even though there were no persons under 20 in the institution by 1900 , only 67 per cent were over 50 . In 1914, 88 per cent of the population was over 50 years old and half of these were between 60 and 80 years old.

Although official records for the perlod between 1916 and 1930 could not be located, a register maintained at the Home between July 15, 1910, and July 12, 1930, reveals a limited amount of data concerning the makeup of the resident pooulation. The register indicates that the number of admissions was high but the number of discharges was proportionately great. There was considerable 1llness and many residents were transferred to the C1ty Hospital and the Waverly Hills Tuberculosis Sanitorium.

The following excerots may be considered as being tyoical of the entries found in the register:

George A. Blacklisted. Assaulted several times. Frank A. Nonresident. Requested to leave. Thomas B. Refused to assist in light work. Discharged. Harry C. Sent from Criminal Court. Idiot. Florence C. To pay 15.00 per month. 
Charles A. Admitted from Lakeland (Central state Hospital) May, 1922. Returned to Lakeland February, 1923.

John C. 6th time admitted. Left.

Thomas T. Promoted to night watchman.

John T. Can work outside but not here. Left.

As might be expected, most of the residents were admitted by the Board of Public Safety. However, the City Hospltal, the Central state Hospital, the Police Court, the Associated Charities, (later the Family Service Organization), the Salvation Army and the Mayor also referred persons to the inst1tution.

Although the register indicated that most of those admitted were over fifty years of age at the time of admission, there are several notable exceptions. There are two instances of admissions of persons who were 19, one in 1910 and another 1n 1926. Several persons were admitted when they were in their twenties, a considerable number in their thirties and a great many who were between forty and fifty.

The register contains two "blachlists," one dated June 1, 1914, and the other February, 1924. The 1914 I1st contains the names of thirty six persons. These persons were not to be readmitted because of drinking, imoudence, refusal to work, refusal to bathe, non-residence, and disorderly conduct. The forty two persons to be refused admittance in 1924, were to be excluded for similar reasons. 
The register does indicate that there was a wide range in the ages of the residents. There was apparently a great deal of illness and there are indications that many of the residents were incapacitated.

The number of residents in 1916 totalled 310. The following table lists population statistics for the institution between september 1, 1932, through August 31,1941 .

\section{Table I}

Population of the Home for the Aged and Infirm between september 1, 1932, through August 31, 1941 (Showing Admissions, Deaths, D1scharges and Averege Resident Population)

Year

September 1

through August 31 $1932-1933$

1933-1934

1934-1935

1935-1936

1936-1937

1937-1938

1938-1939

1939-1940

1940-1941
44

79

49

42

40

64

85

118

103
Admitted

to

Deaths Lakeland

44

43

1

NR

60

46

36

63

58

56

NR

11

other

Average

Resident

pooulation 
These flgures reveal several significant trends. Probably the most outstanding factor is the great increase in the number of admissions during the past three years. The large number of admissions in 1933-34 may have partially been caused by the economic deoression of the early 1930's. With the improvement in business conditions generally, the number of admissions dropped between 1934 and 1937. Beginning with the fiscal year of 1937-1938, the admisgions increased so that by the close of the 1940-1941 flscal year, the number of admissions was almost double the number of the 1931-32 admissions. There were probably several contributing factors which led to this increase. First of all, the restrictive policy of limIting direct relief for the aged group undoubtedly resulted in an adnission of applicants who might otherwise have remained in their own homes. Secondly, the improvement in the medical equipment and facilities at the institution has probably caused the institution to alter 1ts function from being a home for the aged to an institution for the chronically 111. 
B. SURVEY OF THE RESIDENTS IN THE HONE ON JANUARY 1,1942

In an effort to secure an accurate picture of the present resident population at the Home for the Aged and Infirm, a survey was made of the 248 persons living in the institution on January 1, 1942. This survey was made by carefully reviewing the social case record for each individwal for certain specific data. In addition, a discussion was held with the social worker at the Home concerning posstble future plans for each individual. It is believed that by combining the information secured, an accurate, unblased view of the oopulation has been secured.

The following color and sex distribution was found among the 248 residents who were studied:

\section{Table II}

Residents of the Home for the Aged and Infirm on January 1, 1942, by Sex and Race, According to Number and Percent

\begin{tabular}{lcccccc} 
& \multicolumn{2}{c}{ Total } & \multicolumn{2}{c}{ Male } & \multicolumn{2}{c}{ Female } \\
Race & Number & Percent & Number & Percent & Number & Percent \\
Total & 248 & 100 & 178 & 72 & 70 & 28 \\
White & 133 & 54 & 100 & 40 & 33 & 13 \\
Negro & 115 & 46 & 78 & 32 & 37 & 15
\end{tabular}


These figures comore favorably with the statistics I1sted in the Annual Report of the Department of Welfare for the fiscal year ending August 31, 1941. According to the 1941 Annual Report, the male white residents made up 40 per cent of the group, the negro male residents totalled 35 per cent, the white women comprised 13 per cent and the negro women made up the reraining 12 per cent.

It is probably significant that the negro group comprises 46.37 per cent of the population at the Home although this group makes up only 14 per cent of the population of the city. The lack of opportunity for successful competition in employment, the necessity of dolng heavy, unskilled labor and the enforced low economic level have undoubtedly hastened physical breakdown among our negro pooulation and is reflected in the disproportionate number of this group who have had to accept institutionalization. The inability of the male negro worker to conserve any adequate portion of his low wage may In part explain the comparatively large number of negro women in the Home.

Although the average age of the residents is 67.74 years, the survey indicated a range from a low of 25 to a high of 92 . The age distribution 18 as follows:

\section{1}

I6th Census of the United States, 1940 , (U. S. Government Printing office, Washington, D. C.: 1941). 


\section{Table III}

Ages of the Residents of the Home for the Aged and Infirm on January 1, 1942, by Number and Percent

$\begin{array}{lcr}\text { Age in Years } & \begin{array}{c}\text { Number } \\ 248\end{array} & \begin{array}{r}\text { Percent } \\ 100.00\end{array} \\ \text { Less than 30 years } & 1 & 0.40 \\ 30 \text { less than } 40 \text { years } & 4 & 1.61 \\ 40 \text { less than } 50 \text { years } & 10 & 4.03 \\ 50 \text { less than 60 years } & 42 & 17.03 \\ 60 \text { less than 70 years } & 78 & 31.69 \\ 70 \text { less than } 80 \text { years } & 73 & 29.07 \\ 80 \text { less than 90 years } & 38 & 15.35 \\ \text { Over 90 years } & 2 & 0.82\end{array}$

As might be expected in view of the average age of the group, nearly half ( 48.72 per cent) are between 50 and 60 ." years old. Over three-fourths ( 77.79 per cent) are between 50 and 79 and ninety three percent are between 50 and 89 . However, fifteen individuals, or 6.04 per cent, are younger than 50. In addition to the one individual who is only 25, one was 34 , three were between 35 and 39 , three were 40 but Iess than 45 , and seven were over 45 but less than 50 .

The presence of these younger individuals in an institution named the Home for the Aged and Infirm is inconsistent but further examination of the case records affords insight as to why these individuals have been admitted. 
Number 214 is a white man, 25 years of age, who was admitted in November, 1941. In 1940 he had married a woman twenty two years his senior because, according to his statement, she was sorry for him becauge he was homeless. He and his wife were separated in 1941 and her present whereabouts are unknown. He has been dagnosed as suffering with epllepsy. As his condition did not merit institutionalization in a mental hospital, and since he was homeless and without resources, he was admitted to the Home, where he could receive adequate medical care and suoervision. According to the social worker, he will probably remain in the Home indefinitely.

Number 94 is a white man thirty four years old. He was first admitted in November, 1940, discharged, and readmitted in November, 1941, at the request of the County Jaller. A former tobacco worker, he is single and completed the 4th grade in school. Admission was requested since he was paralyzed from his walst down and as he was comoletely without resources. The man had previously been known to the City Hospital in 1930 and the Municipal Relief Bureau in 1934. In view of his physical condition, indefinite care seems indicated.

Number 53, a negro woman who appears much older than 38, the age she has given, was admitted in November, 1940, because of a hypertensive heart condition and cerebral accident. A friend who had assisted financielly could no longer continue to do so.

Number 46 , a white man of 37 , suffers from a congenital hip deformity which has incapacitated him completely. He was admitted in June, 1940. He had completed three years of high school and is an excelilent shoemaker.

Number 147, a white man of 34 , was admitted in June, 1940, suffering with central nervous system Iues and tabes. There is a possibility that he may be placed with relatives. 
Number 2 , a negro woman who is 43 , was admitted in January, 1941, following her release from the Central state Hospital, where she had been a patient since 1931. She is suffering with General Paresis and is in need of supervised. care.

Number 99 is a negro single man believed to be 43 years old. He was admitted at the request of the Family Service Organization in February, 1924. His condition has been diagnosed as lues and left hemlphegla and permanent hospltalization will be necessary.

Number 146 is a negro man who was a known beggar. He suffers with chronic osteomyelitis. Now 47 , he was admitted in 1933.

These illustrations indicate that although many ind1viduals were admitted at a comparatively young age, in practically every instance two factors appear prominently. First, a serious physical or mental problem exists, and secondly, lack of specialized facilities to care for these individuals. In view of this lack, it seems inevitable that many such persons w1ll eventually seek admission to the Home and be accepted for care.

A study of the dates of admission indicates that over half of the residents have been admitted since January, 1939. However, admissions range from 1904 to 1941. The following table shows the number of admissions by the year of admission: 


\section{Table IV}

Length of Stay of Residents in the Home for the Aged and Infirm on January 1, 1942

Length of Stay

Less than 6 months

6 months less than I year

1 year less than 2 years

2 years less than 4 years

4 years less than 8 years

8 years less than 16 years

16 years less than 32 years

over 32 years $\begin{array}{cr}\text { Number } & \text { Percent } \\ 248 & 100.00\end{array}$

$40 \quad 16.1$

$34 \quad 13.7$

$42 \quad 17.0$

$46 \quad 18.8$

$30 \quad 12.7$

$36 \quad 14.5$

$13 \quad 5.6$

$4 \quad 1.6$

Of the 248 persons residing in the Home on January I, 1942, 74 had been admitted during 1941. Fifty seven per cent of the group had been admitted since January, 1939, and approxlmately two thirds had entered during the five years preceding 1942. About one fifth, 18.79 per cent, had lived at the Home for ten years or more; 7.63 per cent had been residents from 10 to 15 years; and twenty three, or 9.23 per cent had been admitted prior to 1927 .

In view of the fact that a majority of the residents had been admitted after the organization of the Department of Public Welfare in 1930 , it seems apparent that most of the residents had been admitted as a result of their apolication to 
the Municipal Bureau of Soclal Service. The survey indicated that 181 of the 248 residents were admitted by that agency. The remaining 67 were admitted by the following sources:

\section{Table V}

Sources of Referrals other Than the Municlpal Bureau of Social Service of Residents of the Home for the Aged and Infirm on January 1, 1942

\section{Number}

Board of Public Safety 22

Loulsville Gity Hospital 28

Division of Old Age Assistance, 5 State Department of Welfare

Psychiatric Clinic, 1 Louisville City Hospital

Sisters of the Good Shepherd 1

Baptist Church

Family Service Organization

Juvenile Court

The large number of admissions by the Board of Public Safety, the predecessor of the present Welfare Department, and the City Hospital are readily understandable. Through a recent agreement with the Old Age Assistance Department, that agency is now permitted to make referrals directly to the institution. The following are examples of referrals by that agency: 
Number 17 is a white woman of 83 who is unable to walk and can no longer care for herself.

Number 52 is a negro man, age 71 , diagnosed as senile.

Number 150 is a white man, age 69, with arteriosclerosis.

In each of these instances, the individual has been unable to care for his or her own personal needs.

The one person referred by the Psychiatric Clinic of the hospltal was a white man, aged 58, diagnosed as suffering with hypochondria and possible senility.

The one person admitted by the Convent of the Good Shepherd was a white woman, age 72, suffering with arterio-sclerosis. She had been a patient at the Central State Hospital for two years.

An interesting point noted in the survey was that five of the residents in the Home were admitted at the request of the Central State Hospital. These persons had been diagnosed as suffering with chronic alcoholism, paranola, chronic dementia, senility and epllepsy, respectively. Four of these had been admitted during 1941 and the other entered the Home in 1922. One of these persons, suffering with paranoia, had spent 20 years at the mental hospital, and another, with chronic dementia, had spent 24 years at a mental hospital. The referral of these persons is probably a result of the efforts on the part of the hospital to ease the serious overcrowding by removing all patients possible. 
As might be expected, most of those admitted to the institution were either single or widowed at the time of their admission. The survey revealed the following marital status of the residents at the time of admission:

$\begin{array}{lr}\text { Single } & 87 \\ \text { Wi dower } & 56 \\ \text { Separated } & 39 \\ \text { Widow } & 33 \\ \text { Divorced } & 19 \\ \text { Married } & 12 \\ \text { Unknown } & 2 \\ & 248\end{array}$

The following illustrations indicate the reason for the admission of the married group:

Number 43 is a negro man of 58 , sufferling with paralysis. He has been a resident since June, 1941. The Municlpal Bureau of Social Service is assisting his wife and four children. Institutionalization was necessary as his wife was physically unable to give him the constant care he needs.

Number 76 is a white man of 61 , who is oaralyzed. He was admitted in 1938 and has been bedrast since 1934. His wife cannot give him the necessary care.

Number 79 is a white man of 67 , who was transferred from the Central state Hosoital. His diagnosis is psychosis with cerebral arteriogclerosis. His wife visits him regularly but is afreid to have him return home.

The educational attainments of the resident group were studied in an effort to secure further data concerning the 
group. The case records reviewed indicated the following:

\section{Table VI}

Educational Attainments of Residents of the Home for the Aged and Infirm on January 1,1942

$\begin{array}{cc}\text { Grade Completed } & \text { Number } \\ \text { None } & 67\end{array}$

1

2

18

3

16

4

19

5

14

6

12

7

6

8

34

9

2

10

2

12

6

14

1

16

2

It should be noted that the information given in the records concerning educational attainment is the unverified data given by the residents. In 37 instances, over 14 per cent of the total population, the grade attained is unknown and two of the residents had only "IIttle" education. One resident attended a commercial school and another attended a private school. The outstanding factor noted is that only 
15 of the residents attained a level higher than the elghth grade.

The following excerpts will partially explain the presence in the institution of the 15 persons professing education above the eighth grade.

Number 153, who completed the 9 th grade, age 81 , had worked as a machine pattern maker. He was admitted in 1937, when he was found to be suffering with malignancy of the stomach.

Number 156 , a wh1te man, age 60 , was admitted in 1931, suffering with cancer of the esophagus. He had been a mortician and had completed the tenth grade. (This man died in January, 1942.)

Number 74, a white man, age 67, a high school graduate, was admitted in 1941 because of a cerebral accident. He had been employed as a laundry machinist.

Number 218, a white woman, age 89, a high school graduate, was admitted in 1941 because of a complication of diseases. She had been a teacher prior to 1921 when she was admitted to a private home.

Number 242 , a white man of 81 , was admitted in 1939 because of a heart disease. He had completed two years of college work and had worked as a teacher and salesman.

Number 165, a white man of 72 , was admitted late in 1941. He had been arrested because of begging and vagrancy. He stated that he had formerly operated a wholesale coal business. According to the Home physician, this man was diagnosed as suffering with senility.

In view of the limited education recelved by the large portion of the residents, it seems apparent that practically all of the residents were either laborers or tradesmen. S1xteen of the residents, all women, had never been employed. 
The type of work done by three others was unknown. The survey revealed that fifty six different occupations had been followed by the remaining 229 residents. The largest group, 79, had worked as laborers, and the next largest group, 42, had been domest1c servants. The occuoations followed included various tyoes of factory labor, salesmen, restaurant workers, porters, farmers, janitors, bartenders, stable boys, barbers and bakers. A number did highly skilled work such as machine operators, painters, carpenters, weavers, steam shovel operators and blacksmith. The list includes several notable exceptions incluaing a morticlan, one minister and a wholesale coal dealer.

In studying the present pooulation of the Home, considerable attention was given to the physical diagnosis made by the Home physician conceming each resident. In many instances residents were found to be suffering from a number of diseases, a condition which might well have been expected in view of the advanced age of most of those studied. In only one instance did the case records fall to include the physical diagnosis of a resident. In this instance, the individual, a white man of 70 , had been admitted in 1926 . He refused to apply for an OId Age Assistance grant as he preferred to remain in the institution.

The survey revealed quite clearly that the Home has assumed the function of a hospital for the chronically 111. Those residents suffering with serious heart conditions, as might be 
expected in view of the average age of the group, comprised the largest number. Sixty seven, or 27 per cent, were diagnosed as suffering with hypertensive cardio vascular heart disease, arterio-sclerosis or chronic myocarditis. The next group, number 40, was diagnosed as having senile osychosis. There were sixteen who were paralyzed and fifteen presented complications due to advanced age. Syohilis was found among many of the residents and was directly attributed as the cause of disability in four instances. However, two of the residents were paretic, and an additional seven were found to have central nervous system lues.

The fact that mental illness or mental deficiency is prevalent among the residents is indicated not only by the large group who are senile, but also by the fact that two of the residents were found to be suffering with paranola; in one instance the diagnosis of psychoneurosis was made, and seven of the residents were classed as feeble minded or idiots. The following illustrations reveal some information regarding this group:

Number 109 was transferred to the Central state Hospital from the Home in 1921 . She remalned In the mental hosoital until october, 1941, and was then readmitted to the Home. She is a negro woman of 70. Her diagnosis is parenola.

Number 256, a white man of 70, was admitted in 1940. Although he has been diagnosed as having paranoid trends, the doctor has indicated that he may be dlgcharged if some plan can be made for him. 
Number 77 is a white man, age 57, who was admitted in 1940. He has been a patient at the Psychiatric clinic of the City Hospital for a number of years. one arm was orlginally paralyzed but the psychiatrists have stated that this is due to hysteria. He has resoonded to treatment and is now able to use this arm to a limited extent. He is currentIy assisting in the kitchen at the Home. His diagnosis is psychoneurosis and hysteria.

Number 122 is a white woman, age 65, admitted in 1909. She has been found to possess very limited mental capabilities and has been classed as feebleminded.

Number 240 is a white woman, age 57 , who had been completely deoendent uoon her family unt1l her admission to the institution in 1937. According to the physician, she is considered an ldiot.

Three of the residents were found to be suffering from chronic alcoholism. For examole, Number 248, a white man of 75 , was admitted in 1940, beceuse of alcoholism and melnutrition. He had been receiving an 01 d Age Assistance grant of \$12.00 monthly.

The survey indicated that elght of the residents were blind. One of these, number 86 , has been a resident for 38 years and is now only 56. He is considered feebleminded. Two of the residents have no legs, and elght have only one leg. In addition, a number are criooled and get around only with difficulty.

The remaining regidents suffer from a wide variety of alseases. Included in the diagnoses found were tuberculosis of the bone, cerebral hemorrhage (5 residents), cerebral accident ( 7 residents), locomotor ataxia, osteomyelitis, 
progressive muscular atrophy, epllepsy ( 4 residents), diabetes and cancer.

In surveying the reasons for admission to the institution, it was learned that in almost every instance two factors were present. There were a lack of financlal resources and a need for constant medical care. In the case of those residents admitted prior to 1930 , no reason for admission is given but in every instance these residents are ohysically incapacitated. In several instances, the individual had been dependent upon relatives over a long period of time and these relatives were unable to continue assuming this responsibility. Many individuals who had been receiving 0ld Age Assistance were admitted when constant supervision was found necessary. An interesting and highly significant factor revealed by the survey was the fact that 92 of the residents, or 37 per cent of the total number, had never been known to a 100al social agency prior to their admission to the institution. However, since the records concerning the 33 residents admitted prior to 1930 contain no Soc1al Service Exchange clearings, no data is available which would clearly indicate whether this group had previously been assisted by a soclal agency. The following table indicates the agencles which have been interested in the residents: 
Table VII

Agencles which had assisted Residents of the Home for the Aged and Infirm on Jenuary 1 , 1942, prior to the date of their admission

Municipal Bureau of Soctal Service 95

Loulsville City Hospital 57

Saint Vincent de Paul 2

Family Service Organization 38

Old Age Assistance 24

Centrel state Hospital 4

Salvation Army 2

Juvenile Court

224

These figures do not include those persons who were accepted by the Municloal Bureau of Social Service for admission to the Home only. The 95 listed as having recelved care by that agency were assisted financially for varying periods prior to their admission.

The 24 residents who had been known to Old Age Assistance represents those persons who had been recelving grants but who needed medical care as well as those who had applied for grants but whose applications had been rejected.

As previously mentioned, each resident was discussed with the social worker and the possible future plan for each resident was reviewed. After a careful review of each resident, it was felt by the social worker that 202 of the res1dents would probably remain in the institution indefinitely. 
Approximately fifty per cent of this group was in need of constant medjcal care. There were forty two residents who might be able to leave the institution if old Age Assistance were granted. Two of the residents were in the institution only for a temporary period and there was a possibility of placement outside of the Home for two of the residents.

It is interesting to note that 14 of the residents had previously informed the social worker that they preferred to remain in the institution rather than to accept old Age Assistance, which would necessitate their leaving the Home. The Louisville Courier Journal on October 14, 1941, stated that many of the residents were refusing to apply for old Age Assistance, preferring to remain in the Home. The article quoted one of the residents as making the following statement: "What would. I do with that pension? Why, for $\$ 40$ I couldn't get what I'm getting here: a clean bed, nice meals, church and tobacco." This individual, a white man of $7 I$, has been a resident at the Home since 1933. He needs constant medical care as he is suffering with a chronic illness.

Several of the residents were interviewed in an effort to determine their reasons for desiring continued institutionalization. In each instance the resident stated that it would not be possible to manage financially outside the institution on a \$15 01d Age Assistance grant. The residents interviewed also apporently preferred the security offered by institutional 
Iife and hesitated to again assume the responsibilities they would have to assume outside the Home.

Both of the residents who were admitted to the institution for temporary care, had been in the Home for only a short period. One was a white man of 57, admitted in August, 1941, following an operation. He will be reemoloyed as soon as his physical condition permits. The other, a colored woman, age 65, was admitted in December, 1941, as she was homeless. She is in good health and plans to leave the Home as soon as she receives Old Age Assistance.

One of the two persons for whom the soclal worker believed placements might be arranged, left the institution in Jenuary, 1942. The other resident in this category is a white man of 35 whose diagnosis central nervous system lues and tabes. There was a possibility that he might be returned to the home of relatives.

Elght of the residents who were to remain in the ingtitution died in Janunry, 1942. Another resident was in jail on December 30,1941 , but was later returned to the Home.

The recommendations made by the social worker compared favorably with the findings made by a committee from the MunicIpal Bureau of Social Service, the soclal worker at the Home, and the institution's physician in a study made in 1941. Sixty nine of the residents had asked to be permitted to apoly for Old Age Assistance. Before apolications were taken, the commlttee reviewed the records of each individual and the doctor 
examined each member and gave his recommendations. It was recommended that only six of the sixty nine be released. The committee felt that 35 should not be released because of their physical or mental condition. Twenty two could be discharged if suitable boarding homes and adequate supervision could be secured. The recommendations for six residents were deferred unt1l additional medical reports could be secured.

To summarize, the survey revealed that the resident population on January 1,1942 , consisted of 248 individuals. Approximately three fourths of this number was male and there was a falrly even distribution between the white and negro groups. The average age of the residents was 67.74 , but the ages ranged from 25 to 92 . Those living in the institution at the time of the survey had resided there from a few days to 37 years. The vast majority, however, had been at the Home for less than 10 years and over half had lived there three years or less. Over 70 per cent of the residents were single or widowed at the time of their admission, the others being separated, divorced or married. In most instances the educational attalnments were less than completion of grade school. Most of the residents had done unskilled labor. Almost every one of the residents was suffering with a chronic illness. Finally, it was believed that continued institutionalization would be necessary for aporoximately eighty per cent of the residents. 
CHAPTER V

MEDICAL CARE 


\section{MEDICAL CARE}

Since the time of its inception, medical care for the residents has always been an imoortant part of the function of the Home for the Aged and the oroblem of providing adequate professional care olus securing facllities necessary for adequate treatment has been great.

The Charter of 1828 mentions that the "Poorhouse" was to serve "Indigents and infirms." According to the 1832 Directory, the combined Poor and Workhouse accommodated "the ooor of the city as well as the sick" and was "attended most honorably by the medical faculty, gratuitously."

There is no information available concerning the standards of medical care or of the medical facilities existing at the Almshouse prior to 1857. It is known, however, that the City of Louisville Charter of 1851 explicitly provided for the addition of a doctor to the staff of the Almshouse. The medical care of the Almshouse was conferred upon the elected physician of the Western District of the city, who was to treat all residents free of charge. He was required to visit the inst1tution at least once daily or oftener if necessary. In addition to treating the 11l, the physician was to supervise the

1

Oliver H. Stratton and John M. Vaughan, oD. cit., o. 53. 2

Louisville City Directory, (Louisville: Richard w. otis, 1832), p. 144 . 
activities of the nurses and attendants.

The Annual Report of the Trustees of the Almshouse for the year ending larch 10, 1857, indicates that the superintendent, Joseph W. Putman, was also a physiclan. Although he did not serve as physician for the institution, he was able to act as apothecary, male nurse and guardian. Dr. E. K. Seeley, the Almshouse physician, in his report for 1857, reported twenty deaths at the institution during the year, s figure Which he consldered as being small in view of the "class of adult inmates and the great number of small children that are brought together." Dr. Seeley reported 243 cases of sickness during the year. The diseases treated included five cases of blindness, three instances of convulsions, fourteen patients with diarrhea and dysentery, four of whom died; three cases of epliepsy, and twenty five with intermittent fever. Two of the residents were diagnosed as suffering with hydrocephalus and five others were idiots. Fourteen were treated for paralysis, eight for phtisis (five deaths) and seventeen for ophthalmia. Venereal disease was present with two cases of gonorrhea and six cases of secondary syphlils. There were eight pregnancies among Almshouse residents during the year.

3 1851, (Louisvilie: W. N. HeIdeman and Co., 1854), p. I62. 
As far as can be ascertained, there was no segregation of elther sexes or adults and children. There were no hospltal wards and the well and sick shared the same quarters. From Dr. Seeley's reoort, it can be seen that the institution!s pooulation was apparently made of persons of all age groups and in every physical condition, incluaing the tubercular, eplleptic, idiots, pregnant, paralyzed, blind and venereally diseased. Considering the vast amount of illness, the mortality rate was surorisingly low.

No data could be located conceming the institution between 1857 and 1866 and nothing has been learned concernIng medical care during this period. In 1866 Dr. R.C.C. Jones, the attenalng physiclan reported that there was little 1llness and that most of the cases were chronic. The most important need, from a medical standooint, was a

"ward or room in which patients needing special treatment may be olaced, at one end of which a small room should be partitioned off for an examining room. This room could be used as a lying in room in case it was necessary to retain some person in the Almshouse in consequence of the crowded conditions of the wards of the city Hospitel, as has been the case since I have been connected with the Almshouse. The sick and well are now necessarily keot together." 5

4

Annual Reoort of the Trustees of the Almshouse of the City of Loulsville for the Year Ending March 10, 1857 , (Louisville: Hull and Brother, 1857).

5

Annual Communication of the Mayor and Reports of the Deoartments of the City of Loui sville for the Year Ending December 31, 1867, (Loulsville: Bradley and Gilbert, 1868), ․ 8. 
Dr. Jones's reference to the transfer of patients from the City Hosoital is the first mention of a practice which has continued up to the present time. The General Hospital has been enlarged periodically to meet the constantly increasing demands for hosoital care. The Hospital has been able to care for the acutely 111 but its facilities have not permitted the admission of the chronically, though not acutely, incapacitated. This latter group includes those suffering w1th various heart diseases, cancer, and general infirmities accompanying old age. Surgical cases, involving long time bed care, are also generally included. This lack of bed space, equioment and medical personnel have tended to cause many persons needing medical attention to accept admission into the Almshouse. There has been a trend in recent years toward converting the oresent Home for the Aged into a hospital for the chronically 111 and the number of residents admitted to the chronic ward has constantly increased.

The year of 1868 witnessed several notable achievements. During this year the first diet table was established, orimarlly for nursing mothers. There were many breast fed babies in the institution during the year but none died, according to the physician, because the mothers were olaced on an extra diet and plentifully supplied with beer. Along this same line, Dr. John J. O'Reilly, the Almshouse physician, defended his apoarently excessive prescribing of liquor as 
medicine. His defense was that the regidents were used to arinking and that whiskey was a necessary stimulant. Deoriving them of their stimulant would interfere with the operation of their digestive organs. The patients would then become confirmed invalids or soon die. Dr. O'Reilly pointed out that whiskey was cheaper than medicine.

The first attemot at segregation of the sexes was made in 1868, when a fence was erected, both in the yards as well as in the building. This segregation resulted in a marked improvement in discloline and morals. Dr. O'Reilly stated that the Almshouse was now (1868) "not where the city 'breeds' her poor but where she 'breads' them."

The succeeding ohysic1an, W. Walling, in 1869, remarked that the use of whiskey had been greatly cut. During that year the institution had experienced a great deal of 1 Inness and overcrowding. The city Hospital had continued to refer a great number of patients to the Almshouse. In his report in 1870, Dr. Walling describes his impressions of the residents by writing that "the class of patients met with here is pecullar, being either old and decrepit, worthy objects of a city's

\footnotetext{
6

Municloal Reports for the Fiscol Year Ending December 31, 1868 , (Loulsville: Bradley and Gilbert, 1869), 0. 24.

7

Ibid., ‥ 25 .

8

Ib1d., 1870, p. 8.
} 
charlty, women burdened with the care of one or more children, or men, who by reason of infirmity, are incapable of further assisting themselves." Dr. Walling complained that overcrowding was resulting because a large number of patients were the "incurables, suffering from cancer or pulmonary consumotion."

The diseases treated in 1870 included cancer, cataracts, narcotism, alcoholism, opthalmia, epllepsy, abortion, polsoning by opium and all three stages of syphills. Deaths and disease were confined chlefly to the very young and the very old.

Although a new and enlarged bullding was erected in 1874, this bullaing ald not, so far as can be determined, include hospital wards for the residents. The Annual Report for the year ending August 31, 1894, contained the following letter addressed to Mr. R. J. Tilford, a member of the Board of Public Charities:

At your request I send you the dimensions of hospital wards to be built in the yard of the Almshouse. Two rooms, one in the female yards and one in the male yards, 90 feet long, 45 feet wide, celling 18 feet high. Building to be built out of brick, with a tin roof, and partition in the midale of each (builaing). 10

9

Ib1d., 1871, pp. $327 \mathrm{~F}$.

10

Ibid., 1895, o. I. 
By the close of 1897, the Board of Public Safety was able to report that one charity hospital and one home for pauper idiots had been built and properly ecuipoed. These were actually merely new buildings erected on the grounds of the Institution. 11

Official records which would reveal data concerning the standards of medical care at the Home between 1916 and 1930 could not be located and little is known concerning the pol1cies in effect during that period. There are indications, however, that there was close cooperation between the inst1tution and the City Hosoltal. The Home for the Aged Register from 1910 to 1930 indicates that the City Hospital patients were frequently referred to the Home for institutionalization.

In 1930, a clinic was ooened for the residents and the institution's physician held of fice hours dally. Mr. M. D. Hall, Clty Comptroller and Inspector, in his reoort to the mayor on February 17, 1931, noted that considerable progress had been made within the preceding year in the medical care of the residents. The former arug room had been converted into a. clinic and drug disoensary. A ohysician had been emoloyed. to, spend a part of each cay making medical examinations and the Health Deoartment was furnishing dentists for the residents. According to Mr. Hell, this medical aid had long been

11 Ib1d., 1897, p. 3. 
needed and relieved "the congested conditions at the City Hospital to the extent of an average of fifteen patients daily."

There were two hospital wards in the Home, one for white men and one for white women. Twenty two of the white residents of both sexes were classified as being chronically ill. Since there were 94 negro residents, four of whon were chronically 111 , as contrasted against the 199 white residents, it is difficult to understand why no hospital wards were orovided for the negro group.

Dr. Franklin Jelsma, physician for the Home, in a comolete statement concerning medical activities at the inst1tution during the year, reported several major changes. Ward rounds of hosoital patients were made daily and direct contact was keot with every oatient having some complaint or disturbance. Those who were found to have a sufficient degree of disease or incapacitated by a chronic or acute condition mere moved to the hospital ward of the Home. There were wards for white and negro male residents as well as for white women. No female negro hospltal ward had opened because of the lack of 14

room in the female negro cuarters.

12

Report of the City of Louisville Comptroller and Insoector, (Louisville: February 17, 1931), 0. 4.

13

Ib1d., p. 5 .

14

Annual Report of the Deoartment of Public Welfare for the Fiscal Year Ending August 31, 1932, (Louisvilie, 1932), o. 6 . 
The hospital wards were reported as belng well equipped, well heated and adequately ventllated. Facillties for hosp1tal patients included 17 beds for white men, 9 for negro men, and 16 for white women.

An arrangement had been made with the City Hospitel whereby City Hosoltal patients convalescing from an acute 1llness or those suffering from chronic 1llnesses, might be admitted to the hospital at the Home. Through this plan, the City Hosoltal would be afforded more bed sorce for the acutely 111 and some of the City Hospital congestion would be relieved. Under this arrangement, nine white men, one white woman, nine negro men and four negro women were moved from the C1ty Hospital to the Home. Since Dr. Jelsma believed that there would be a City Hosoltal turnover every ten days in beds used by the acutely 111 , the removal of twenty three patients necessitating long time hospital care, really afforded considerable bed soace for City Hospital patients. There was a need for additional equipment such as stretchers and wheel chairs, according to Dr. Jelsma.

During the past ten years increased emohasis has been placed uoon the medical care of the residents and there has been a gradual trend toward converting the institution into a hospital for the chronlcally ill. In the 1935 Annual Report, Dr. Vick, the suoerintendent, noted that admissions

15

Ib1d., p. 7 .

16 Ibld., pp. 7-9. 
were being limited almost entirely to the chronically incapacitated. This factor led to numerous changes in both the physical plant and in the stafe.

Mr. Charles J. Rieger, Jr., Director of Welfare, stressed the changing function of the Home in his Annual Reports for both 1939-1940 and 1940-1941. The following statement apoeared in the 1939-1940 Annual Report:

I vould like to emohasize that the hosoltal function of the Home is becoming increasingly more real as time goes on. All bed patients have been moved to the first floor, both as a safety measure and to exoedite handling. From our supervising nurse our attendants are recelving periodic training in nursing care which is being further supolemented through the aid of a trained nurse provided for the ouroose by the Works Projects Administration. We also hooe to soon establish a consultant staff of physicians to assist in our work.

As vacancies (in staff) arise at the Home for Aged, we would like to make certain reolacements with trained nurses.

I am confident that in the near future the Home for the Aged and Infirm will become a chronic hospital for the aged. Our planning must continue to be directed toward this development which perhaps will have to be tied in with a general chronic hosoital. The need of such an institution has already been cited in detail by persons in close touch with the situation.17

The Municipal Bureau of Social Service, in its report for 1939-1940 also indlcated a change in emphasis in its

17

Annual Report, Department of Public Welfare, City of Louisville, 1939-1940 (Louisville: 1940), op. 3 f. 
pollcies regarding admission to the Home. The Bureau's report includes the following statement:

Although admissions to the Home for the Aged and Infirm in the past were based solely on age and indigency, during this year a new use for the Home became aparent. In analyzing the "single" case load of the Municioal Bureau of Social Service (which constituted 40 per cent of the entire load), it was found that 4 per cent of these individuals were bedfast, while another 31 per cent were chronically 111 and in need of care not avallable to them in their own home. A number of single cases currently referred to the Bureau required medical care, soecial diets and bed rest, and 1 t was possible for the agency to supoly this specialized care at the Home for the Aged at a Ilmited cost. Arrangements were made to care for all bed patients, the very feeble and those requiring institutional care at the Home.18

Although numerous changes had been made in the past decade in the physical plant to provide additional facilities necessary for adequate medical care, Dr. Vick stated that in 1914 there was a need for still more hospital beds, wheel 19

chairs and infirmary attendants.

It seems apoarent that the Home for the Aged and Infirm is gradually being converted into an institution for the chronically 11l. The chronic sick are largely persons with advanced diseages of the heart and arterfes, with disorders of the nervous system, including all sorts of paralyses, with chronic rheumatism and persons physically handicaoped from

18

Ibid., p. 23.

19

Ibid, $1941,0.34$. 
accidents that have resulted in loss of Iimbs. While many of them are old, a number are between 20 and 50 . These persons need various types of care and may be classified as follows:

Class A: Persons in need of active and continuous treatment by a physician.

Class B: Persons who need chiefly skilled care by a trained nurse.

Class C: Persons who require only care by practical nurses or attendants, with medical and nursing supervision.20

The Joint Committee on Hosoital Care of the American Hospital Association and the American Public Welfare Association has stated that individuals belonging in either Class A or Class B should be cared for in a hospital and that no attemot should be made to care for them in a home converted from an almshouse. The latter groun, Class $\mathrm{C}$, may be cared for in a converted institution.

The Joint Committee has formulated minimum standards for institutions caring for chronically 111 persons who fall within Class C. A comparison of the care available at the Home with the standards set un by the Jolnt Committee will afford some Iight as to how adequately these standards are being met at the present time.

20

Institutional Care of the Chronically Ill (Chicago, American Public WeIfare Association, 1940), p. 7 .

21

Ib1d., pp. $7 \mathrm{f}$. 
According to the Commlttee, the size of the building will be dependent upon the number of residents. In all bulldIngs of more than one story, elevators should be provided. The rooms should accommodate two to $s 1 x$ persons but not more than six, and locker space, a bedside table and a chair should be orovided for each person. There should be a number of single rooms for speclal cases. Sitting rooms and assembly rooms for recreational purposes are necessary. The tollet and bathing facilities should be easily accessible. All reasonable sanitary provisions should be available. Some provision for ohysiotherapy would be desirable. Arrangements should be made for taking patients in and out of doors in wheel chairs. Medical facilities, a small drug room, an 1solation room or rooms and a section set aslde for use as an infirmary in cases of acute illness should be included.

The Home for the Aged and Infirm is a three story brick bullding, which was erected sixty eight years ago. Its maximum capacity is aporoximately 250. Although the need for an elevator has long been stressed, this need has not been met.

The first floor is used primarily for hospital wards and administrative offices. There is complete segregation of the residents both as to sex and color. All of the men reside in one half of the bullding and the women occuoy the

22

Ibid., op. $11 \mathrm{f}$. 
opoosite half. The first floor contains the following rooms:

Five rooms for white female bed patients, with three to five occupants per room.

Four rooms for negro female bed patients, with three to seven residents per room.

Four rooms for negro female ambulatory residents, five to seven persons in each room.

Five rooms for white male bed patients, four to ten patients in each room.

Three rooms for negro male bed patients, four to seven per room.

Four rooms for male negro ambulatory residents, five to seven occuoants per room.

General office

suoerintendent's office

Social worker's office

Interne's quarters

Clinic and Doctor's office

Drug room

Kitchen

Dining rooms

Lavatories and washrooms

women.

A recreation room for negro men and one for negro

It may be seen that facilities on the first floor match the standards set fairly well. The number of patients in each room is rarely over six and in only one room are there as many as ten patients. Each patient has a bedside table and one or more chairs. Since the residents on the first floor are pri- 
marlly bed patients, the limited number of washrooms and lavatories are probably adequate to meet the needs. The Home's clinic includes an examining table, a dressing cart, sterilizer, microscope, and other minor equioment. Patients occupying beds on the first floor may use ramps to leave the bullding by wheel chairs if they so desire. There is a newly erected sun porch. As previously stated, there is no elevator and the floors are connected by high, iron stairs which make it difficult for many of the residents to go from floor to floor at will.

The second floor contains the following rooms:

Nine rooms for male negro residents, with one to seven residents per room.

Seven rooms for female white residents with two to five residents in each room.

Dining room for white men - capacity 70 persons. Dining room for white women - capacity 20 persons. One recreation room for men and one for women.

The residents who have been olaced on the second floor are mostly ambulatory or semi ambulatory patients. None of these persons are confined to bed all of the time. The third floor contains quarters for 14 white men. A workshop, operated by one of the residents, is also located on this floor.

It should be noted that convalescents transferred from the General Hosoital are intermingled with residents who 
are placed on the first floor. There are usually about 8 convalescent patients at the Home.

The chief lack as to physical equioment seems to be the lack of an elevetor. Installation of an elevator would permit the placing of bed patients on the upper floors and permit the admission of more persons needing bed care. Because of the oroximity to and arrangements with the General Hospital, there is no urgent need for a room for special cases or a section for cases of acute 1llness. There is no provision for physiotherapy.

The Joint Comittee made the following recommendations concerning the personnel standards:

The superintendent should be a trained person with exoerience in institutional management; a graduate registered nurse experienced in hosoital administration will usually be the most acceotable person.

A physician must visit dally and be on call for emergencies.

Special service should be available for the care of the eyes and for the orovision of glasses.

A dentist must be on call for such services as extractions and artificial dentures.

There should be at least one graduate nurse in charge of nursing care with an attendant and an orderly on duty at night.

Nursing oersonnel, prectical nurses or orderlies should be in the ratio of one to two patients and should be under the supervision of a graduate nurse.

A social worker. 
The services of a chiropodist and a barber are
desirable. 23

As contrasted with these standards, the Home's personnel includes the following; emoloyees:

Superintendent

Principal Clerk

\begin{tabular}{|c|c|c|c|c|}
\hline $\begin{array}{l}\text { Social } \\
\text { Service }\end{array}$ & Medical & $\begin{array}{l}\text { Operating \& } \\
\text { Ma1ntenance }\end{array}$ & Housekeeolng & WPA \\
\hline \multirow[t]{2}{*}{$\begin{array}{l}\text { Social } \\
\text { Worker }\end{array}$} & $\begin{array}{l}\text { Clinic Phy- } \\
\text { sician }\end{array}$ & $\begin{array}{l}\text { BujlIding } \\
\text { Engineman }\end{array}$ & $\begin{array}{r}\text { Infirmary } \\
\text { Watron }\end{array}$ & $\begin{array}{l}\text { Suver- } \\
\text { visor }\end{array}$ \\
\hline & $\begin{array}{l}\text { Sup. Hospital } \\
\text { nurse } \\
\text { Sr. Interne } \\
\text { Jr. Interne } \\
\text { Asst. Pharma- } \\
\text { cist } \\
\text { Infirmary } \\
\text { attendants }\end{array}$ & $\begin{array}{l}\text { Truck Driver } \\
\text { Watchman } \\
\text { Cleaner } \\
\text { Fireman } \\
\text { WPA workers }\end{array}$ & $\begin{array}{l}\text { Head Cook } \\
\text { Kitchen } \\
\text { heloer } \\
\text { Seamstress } \\
\text { Janitress } \\
\text { (and used } \\
\text { clothing } \\
\text { supoly) } \\
\text { Laundress } \\
\text { Laundry } \\
\text { washerman } \\
\text { WPA workers }\end{array}$ & Workers \\
\hline
\end{tabular}

Working in close cooperation with the suberintendent, the suoervising nurse and the social worker, Dr. Armstrong, the institution's ohysician, has office hours dally and soends eoch morning giving treatment. Dr. Armstrong conducts numerous clinics for the residents.

The supervising graduate nurse works with the doctor and social worker and has charge of the 13 inflrmery attendants (practical nurses). These include eight white women, three negro women, one white man and one male negro attendant. The two internes are medical students and they are on duty 
from 5:00 P.M. to 7:00 A.M. The internes recelve a small salary plus room, boerd and laundry.

The social worker assists the superintendent, the doctor and the nurse. She has been a member of the staff for a number of years. Mrs. Glenn, the social worker, does not aporove admissions to the Home, as this is done by the Municioal Bureau of Social Service.

There is a large group of WPA workers who assist in various capacities in the Home.

In instances of acute 1IIness, the residents are transferred to the Generel Hospital. Dental care is also made avallable through the Hospital or the School of Dentistry. One of the residents serves as barber. Although the standards indicate that the superintendent should be a trained nurse, the institution is probably not ready for a person of this type at the present time. Should the number of bed patients continue to increase rapidly, It may be advisable to have a nurse as superintendent. The greatest deficiency in the matter of personnel at the present is the lack of adequate nursing care. The Joint Committee has recommended a minimum ratio of one nurse or orderly to every two patients. For the approximately 70 bed patients, there are only one graduate nurse and thirteen attendants. The graduate nurse lives in the Home and although she is not on duty at night, she is on call at any time. 
The Joint Committee also set uo minimum standards for medical administration, as follows:

Medical examinations of all residents orior to admission and repeated examinations at least every year.

A system of medical records should be adooted and keot un to date. A medical record should be keot for each patient, which would include the medical examination, the laboratory reports, treatment and progress notes.

Social case records should be keot either by the institution or obtained from the welfare agency which regulates admissions.

Persons who develoo serious illnesses should be transferred to a general hosoltal.

Persons who develop osychoses should be transferred to institutions for mental diseases.

Persons vith tuberculosis should not be acmitted and if they later develoo this disease, they should be transferred.

Some provision should be made for giving pa-
tients occunational therapy and recreation. 24

All apolicants for admission are examined at the General Hospiti prior to their admission and a comolete medical report is sent to the Home. The supervising nurse maintains medical recoras on all patients, including the medical chart and a card system which has an accounting of the treatment being given.

The social worker receives a summary from the Munic1pal Bureau of Social Service orior to the admission of each apolicant. It is the duty of the social worker to keep all

24

Ibid., 0.13. 
case records current.

There is a frequent interchange of petients between the Home and the General Hospital, the Hospltal referring. convalescent patients and the Home transferring the acutely i1l. In cases of mental illness an effort is made to arrange admission to the Central state Hospitel. Residents with tuberculosis are referred to the Waverly Hills Tuberculosis Sanitoriun.

Reading rooms and assembly rooms have been provided for the residents. However, it apoears that there is a need for occuational therapy for the residents. This is especially important not only because the majority of the residents soend the day in idleness but because of the theraoeutic values associated with a orogram of occupational theraoy. At the present time, most of the residents arise before 6:00 A.M. and breakfast is served at $6: 30 \mathrm{~A} . \mathrm{M}$. There are no planned activities during the morning, and lunch is served at $11: 30$ A.M. Church services are held during the afternoon. The evening meal is served at 4:30 P.M. and the residents retire about 8:00 P.I. AII Ilghts must be out by 9:00 P.I.

It mey readily be noted that the Home has already taken long strides in its conversion from an institution for aged oersons to a home for the chronically 111 . If this trend is to continue there is an urgent need for the installation of an elevator, the erection of better fire escapes, provision 
for phystotherapy, the purchase of additional wheel chairs, the installation of additional bathing and toilet facilities, the hiring of a dietician, the adition of at least one more social worker and a number of practical nurses, and the inauguration of a program of occupational therapy. 
CHAPTER VI

THE OLD AGE ASSISTANCE PROGRAM 


\section{THE OLD AGE ASSISTANCE PROGRAM}

Prior to the passage of the Social security Act on August 14, 1935, there was much discussion which indicated that the passage of the Act would hasten the elimination of the traditional almshouse from this country. The old Age Assistance orogram has, of course, had a direct effect upon the Home for the Aged and Infirm. It seems advisable to discuss briefly the effect of this program on the institution and to draw some conclusions as to the possible future effect.

In January, 1934, State Reoresentative F. P. Keesie oroposed an 01d Age Assistance orogram for Kentucky. Prov1sions of this bill included monthly payments of $\$ 12$ at the age of 70 . The recipients would have had to reside in the state for at least 20 years, and their income could not be over \$100 oer year. The program would be financed by assessing a three per cent tax on the Kentucky gross premiums of Iife, fire and casualty insurance companies doing business within the state, but having their corporate homes elsewhere. This bill was never passed.

On November 16, 1935, the citizens of the state voted In favor of amending the Kentucky Constitution to permit passage

1

Louisville Courler Journal, Jenuery 31, 1934. 
of an 0ld Age Assistance Act. Of the 610,000 persons voting on this prooosal, 550,000 were in favor of 1 t.

The State Legislature passed an Old Age Assistance Act in February, 1936, after a bitter fight over the maximum grant to be made available. The Legislature finally set \$15 as the monthly maximum grant, although there were many who were in favor of a maximum of $\$ 30$. The law provided that the State could take a lien on any real property owned by a reciolent of a grant.

Federal aporoval of the Act was given in May, 1936, but was later withdrawn when Governor Chandler appointed "a group of inexperienced welfare workers to pay political debts" to administer the orogram. Numerous groups protested the appointments. Governor Chandler admitted the necessity of "olaying politics." He stated that honesty, loyalty and sincerity were the orinciple requirements of emoloyees administering the orogram.

The Federal Social Security Board aoproved the

2

News and Enquirer, November 16, 1935.

3

Louisville Courier Journal, February 15, 1936.

4

Louisville Herald Post, July 24, 1936.

5

Louisville Courier Journal, August 5, 1936. 
Kentucky program and made its first grant to the state, amounting to $2,625,000$ on August 8, 1936.

Since the passage of the original Act, only two changes have been made. In 1940 the maximum grant which could be made was raised from $\$ 15$ to $\$ 30$. The lien provision of the Act was also abolished at the same time. Despite this liberalization, the Legislature appropriated only enough money to provide for the previous \$15 maximum.

The following statistics concerning the old Age Assistance program in Kentucky have been secured from the Annual Reports of the Social Security Board:

\section{Table VIII}

Total Grants, Number of Reclolents and Average Monthly Grant oer Reclplent of Old Age Assistance in Kentucky from July 1, 1936, through June 30, 1941

Fiscal Year

July I through

June 30

Total Grants Reciolents

Average Grant

$1936-1937$

$1937-1938$

1938-1939

$1939-1940$

1940-1941

$$
\begin{array}{r}
\text { W658, } 874.81 \\
2,147,789.63 \\
4,585,000.00 \\
4,764,000.00 \\
5,715,000.00
\end{array}
$$

35,649

33,214

45,028

48,734

57,806

$\$ 9.95$

9.35

8.67

8.74

8.94 
The following figures were secured concerning the amount granted in Loulsville and Jefferson County, Kentucky:

\section{Table IX}

Number of Recioients, Amount Granted and Average Monthly Grant oer Reciplent of old Age Assistance in Jefferson County, Kentucky, in May, 1939, August, 1941, and March, 1942

Reciplents Total Grants Average Grant

$\begin{array}{llrl}\text { May, } 1939 & 3074 & \text { \$32, 830.32 } & \text { \$10.68 } \\ \text { August, } 1941 & 4168 & 44,605.00 & 10.70 \\ \text { March, } 1942 & 3774 & 45,399.00 & 12.03\end{array}$

According to figures secured through the Louisville office of the Division of Public Assistance, 85 per cent of those recelving benefits in Jefferson County in March, 1942, were residents of the City of Louisville. On this basis, there wcre 3,208 01 age Assistance reclolents in Louisville in March, 1942.

Many studies have been made concerining the effect of the Old Age Assistance orogram in eliminating almshouses. A study made in Wisconsin indicated that the program was having little effect. One reason for this is that Old Age Assistance grants cannot be made to aliens. Although allens make up 13 per cent of the population 65 and over in Wisconsin, the aged alien group composes 26 per cent of the almshouse pooulation.

10 Monthly Reoort, Division of Public Assistance, Kentucky Department of Public Welfare, March, 1942. 
Another imoortant factor was found to be the tendency of older oersons to need medical and nursing care. The study revealed that many more persons should have been institutionalized. However, since the counties were forced to contribute only six dollars monthly toward the state's portion of the old Age Assistance grant, and as institutional care cost one dollar per day, many of the counties preferred to issue grants. A similar study was made in Tennessee to determine the effect of the Social Security program on the almshouses in that state. Between Narch 1, 1937, and November 15, 1937, 944 persons out of a total of 2,608 residents were removed from Tennessee almshouses. Of the 944 discharges, 389 received Old Age oensions, 10 received Aid to the Needy Blind grants and 56 recelved assistance through the Ald to Dependent Children program. In November, 1937, there were 762 additional residents who were eligible for grants through the Social Security public assistance orograms.

According to the Tennessee study, the program proved most helpful in those instances where mothers and children were removed from almshouses.

11

"Effect of Old Age Assistance on Wisconsin Almshouses," Survey, Vol. 76, June, 1940, D. 204.

12

"Effect of the Sociel security Program on Almshouses, "Monthly Labor Review, Vol. 17, No. 3, Seotember 1938, D. 518 . 
Sixteen states, most of them oredominantly rural, reported that the Social security Act had led to a noticeable reduction in the almshouse pooulation and that many almshouses hed been closed. However, in sixteen other states little effect had been noted. In this latter group, the almshouses had been used primarily for those in need of institutional care. In some instances the Act hastened the transference of almshouses into hospltals for the chronically ill.

The Old Age Assistance orogram has had Iittle effect on the Home for the Aged and Infirm for many reasons. The foreign pooulation of the city is negligible. At the present time there is only one resident in the Home who is unable to secure a grant because he is a non citizen. Soecialized institutions for the blind, deaf, mentally 111 and the feeble minded have been in operation in Kentucky for many years.

The Deoartment of Public Welfare of the city has been aware of the need for a chronic hosoital and has taken steos to convert the Hone into an institution of this tyoe. In oursuance of this policy, a large percentage of those admitted to the Home since 1936 have been bed patients who are in need of institutional care. These persons are therefore not el1gible for participation in the 0ld Age Assistance program.

A survey of the population of the Home revealed that there were 42 residents on January 1, 1942, who might be able to leave the institution if pensions were grented. Fourteen 
of the residents eligible for grants refused to aoply in view of the limited size of the grant. In most instances, the maximum monthly grant is 15 and many prefer to remain in the institution rather than try to manage indeoendently on a grant insufficient to meet their needs.

The OId Age Assistance program has had only a lim1ted effect on the Home. According to the institution's soclal worker, only 18 residents were discharged between Seotember, 1940, and February, 1942, by reason of having been granted pensions. No new oensions have been granted since February 15, 1942, as the state Department 1s engaged in olacing the Aid to Deoendent Chizdren and Ald to the Blind programs into operation.

It seems probable that as the institution becomes converted into a chronic hosoital that the 0ld Age Assistance orogram will have less and less effect on the number of residents. 
CONCLUSIONS 


\section{CONCLUSIONS}

The Home for the Aged and Infirm is an institution operated by the city of Louisville under the supervision of the Department of Welfare. During the century of the institution's existence it has evolved from a combined Work and Poor House to an almshouse and then to a Home for the Aged and Infirm. At the present time another development seems imminent, the conversion of the institution into a hospital for the chronically ill.

There are several factors which have contributed to the tendency toward increased usage of the Home and other similar institutions throughout the country as chronic hosoltals. Imoortent developments in the private and public social services plus the creation of speclalized agencies for the physically handicapped and the mentally defective or diseased have in many instances minimized the need for the large almshouses of the nineteenth century which served as a dumping ground for all tyoes of individuals in need of care. Public assistance programs have also had some effect in preventing many persons from having had to acceot institutionalization.

As contrasted with the above develooments, there has been a decided trend toward a constantly increasing proportion of the population made up of those persons who are aged. The 
Tenth Census of the United States, made in 1880 , indicated that at that time only 8.1 per cent of the population was fifty flve years of age or over. By 1930, this group made up 12.5 per cent of the total population and there were six and one half million, or 5.4 oer cent of the total population who were 65 years of age or older. The President's Committee on Economic Security reported in 1935 that by $1960,9.3$ per cent of the population would be made up of the groun who are 65 or over.

That the population of the City of Louisville has reflected these same trends is Indicated by the 1930 and 1940 census. In 1930, those persons aged 65 or over comorised 6.6 per cent of the Louisville population. By 1940 this grouo made up 7.7 per cent of the total number.

Closely associated with this increasing age of the population, there may result an increasing number of persons with chronic diseases. As the population continues to grow older, an increasing number of persons with heart disease, senility and diseases associated with old age will possibly result. Because of this factor the need for chronic hospitals may become increasingly pronounced.

Specialized agencies have been in existence in Loulsville and Kentucky for many years but few of these agencies have been able to expand rapidly enough to meet the constantly increasing demands for their services. The early records of 
the Home indicate that many persons in need of medical care at the General Hospital were admitted to the Home because of overcrowded conditions at the hospital. Enlargements have been made periodically to the General Hospltal but even today the hospltal cannot admit persons suffering from chronic illness because of a lack of bed space. The state mental hosoitals are overcrowded and an attemot is being made to discharge as many patients as possible.

Because of the lack of other resources, the sick, deaf, blind, and the feeble minded have been admitted to the Home for the Aged. The administrators have made an effort to eliminate as many of these grouns as possible so that by the end of 1941 the Home was functioning primarily as an institution for the physically handicapod.

The Louisville Department of Public Welfare has been conscious of the gradual trend toward the use of the Home for serving the chronically 111 and has constantly added medical equioment to the institution. However, at the oresent time the institution $1 \mathrm{~s}$ facing a crisis. The entire first floor is being used for oatients suffering with chronic 1IIness who are confined to bed. There 1 available bed space on the second and third floors of the bullding, but the lack of an elevator and sultable fire escaoe provisions make the use of these upoer floors inadvisable.

The major problem, therefore, facing the institution 
before it can be converted into a chronic hospital, are changes necessary in the building. First and foremost, the installation of an elevator seems imperative. Better fire escapes are necessary. The present arrangements meet minimum standards for a chronic hospital. However, additional bathing and tollet equipment might well be added. Should the Home be converted into a chronic hospital, there will be certain administrative difficulties to be cleared up. Would it then be desirable to have it transferred to the Deoartment of Health, or should the Department of Public Welfare continue In its operation of the institution? In the past these two departrents have worked together harmoniously and there is no reason why they could not continue to do so in the future. In the event that the institution is converted into a hospital, it might be preferable that the Department of Health assume suoervision. However, this does not seem I1kely to occur within the near future. It is felt, therefore, that the institution should be continued under the direction of the Melfare Deoartment but that there should be closer tie uo between the two departments. It seems advisable that a closer relationship between the medical staff of the General Hospitel and the ohysician at the Home be formed.

In converting the institution into a hospital for the chronically ill, care must be taken to orovide for the individuals not in need of hospital care but found to be in need 
of supervision. It is believed that a orogram of boarding home care for this group is necessary and should be developed. The Home for the Aged and Infirm will probably not be converted into a hospital for the chronically ill for some time due to a lack of funds on the part of the Department of Welfare. However, the Depertment might welI continue its present progrem of increasing the available medical facilities at the institution. Following this, necessary changes in the physical structure should be made as soon as funds are available. Provisions for physiotheraoy and occurational theray and additionel nursing personnel are bady needed at the present time. Gradual changes in the personnel should be mede so that the adninistration will be equipoed to operate a hospital for the chronically ill as soon as conversion is found possible. 


\section{BIBLIOGRAPHY}




\section{BIBLIOGRAPHY}

\section{A. Books}

Grace Abbott, From Rellef to Social Security, (Ch1cago: The University of Chicago Press, 1941).

Eaith Abbott, Public Assistance, (Chicago: University of Chicago Press, 1940), Vol. 1 .

Herry L. Hookins, Spending to Save, (New York: W. W. Norton \& Co., 1936).

Oliver H. Stratton and John H. Vaughan, A Collection of the State and Municloal Laws in Force and Applicable to the City of Louisville, Ky., (Louisville: C. Settle, 1857).

Revised Ordinances, City of Loulsville, Charter of 1851, (Louisville: W. N. Haldemen and Co., 1854).

Memorial History of Loulsville, edited by J. Stoddard Johnston, (Chicago: American Biograohical Publishing Co., 1896).

History of the Ohio Falls Cities and Counties, 1778-1882, (Cleveland, Ohio: L. A. William and Co., 1886) VoI. I.

Robert $w$. Kelso, The Science of Public Welfare, (New York: Henry Holt and Co., 1932).

Edward T. Devine, When Social Work Wa.s Young, (New York: Macmillan Co., 1939).

Frank Dekzer Watson, The Charity Organization Movement in the United States, (New York: Macmilian Co., 1922).

Amos G. Warner, American Charities, Third Edition, Revised by Mary Roberts Collidge, (New York: Thomas Y. Crowell Co., 1919). 


\section{B. Reoorts}

Annual Report of the Trustees of Almshouse of the Clty of Louisville For the Year Ending March 10, 1857, (Louisville: Hull and Bro., 1858).

Annual Communication of the Mayor and Renorts of the Deoartments of the City of Loulsville For the Year Ending December 31, 1867, (Loulsville: Bradley and Gilbert, 1868).

Louisville, Ky., Munlcipal Reports, 1868-1874, 1876, 1886, 1888-1897.

Louisville, Ky., Annual Reports, Board of Public Safety, 1897-1916.

Louisville, Ky., Annuel Reoort, Department of Public Welfare, 1931-1941.

Report of the City of Louisville Comotroller and Insoector, (Louisville: February 17, 1931).

Annual Reoort of the Social Security Board, Federal Security Agency, (Washington: United states Government Printing office), 1937, 1938, 1939, 1940, 1941.

Monthly Report, Division of Publ1c Assistance, Kentucky State Department of Public Welfare, March, 1942.

C. Newspaper Clippings

Louisville Commerclal, March 11, 1885.

Louisville Courier Journal, October 15, 1916; Aoril 3, 1919; December 1, 1927; June 17, 1933; February 5, 1935; November 30, 1935; February 17, 1939; January 31, 1934; October 14, 1941; February 15, 1936; August 5, 1936; April 18, 1940; July 9,1940 .

Louisville Times, May 9, 1930; August 26, 1939.

Louisville Herald Post, July 24, 1936; August 8, 1936.

Cincinnat 1 News and enquirer, November 16, 1935. 


\section{Miscellaneous}

Encyclooedia Americana, Vol. I, 1941 "Almshouse."

Louisville City Directory, (Loulsville: Richard W. Otis, 1832).

Compllation of the Social Security Laws, Social Security Board, (Washington, D. C.: 1941).

Emil McKee Sunley, "The Kentucky Poor Law 1792-1936," (Unpublished Ph.D. Dissertation, School of Social Service Administration, University of Chicato, 1938).

Loulse Hess Meyers, "A History of the Louisville City Hosoltal," (Unoublished M.A. Thesis, Department of Sociology, University of Louisville, 1936).

Margaret $\mathrm{K}$. Strong, "Public Welfare Administration in Louisville, Ky.," (Unoublished pamohlet, University of Louisvilie, March 20, 1935).

G. Collins, Louisville Directory, (Loulsville: Prentice and Weissinger, 1836).

G. Collins, Louisville Directory, (Louisville: J.B. Marshall, 1839).

G. Collins, Louisville Directory, (Louisville: Hinkle Logan and Co., 184i).

G. Collins, Louisville Directory, (Louisville: A.S. Tilden, 1843).

Mildred E. Bateman, "Lay Participation in the Private Family Agency, Louisville, Ky.," Unoublished M.S.S.A. Dissertation, Graduate Division of Social Administration, University of Louisville, 194I).

Institutional Care of the Chronically Ill, A Report of the Joint Comrittee on Hospital Care of the American Hosoital Association and American Public Welfare Association, (Ch1cago: American Public Welfare Assoctation, 1940).

Kentucky Emergency Relief Administretion, "Care of Deoendent Aged in Kentucky, Including a Survey of the Almshouses in the State," (Louisvilie: Rentucky Emergency Relief Administration, August 1, 1935). 
Eugenia Lea Remeling, "The Hamilton County Home," A Social Survey of the Almshouse in Cincinnati, edited and directed by Ellery Francis Reed, (Cincinnati: Helen S. Troustine Foundation, 1927).

Evans, Harry Carrol, The American Poor Farm and Its Inmates, (Des Molnes: Loyal Order of Moose, the Brotherhood of Amerlcan Yoemen, the Maccabees, the Suoreme Tribe of Ben Hur and

the American Insurance Union, 1926).

"The Louisville Survey, Summary Report, Louisville Community Chest," Community Chests and Counc1ls, (Louisville, March, 1939)

Louisville Department of Public Welfare, Policy Book.

Survey, "Effect of OId Age Assistance on Wisconsin Almshouses," Vol. 76, June, 1940.

Monthly Labor Review, "Effect of the Social Security Program on Almshouses," VoI. 17, No. 3, september, 1938. 
APPENDIX 
RULES OF THE HOME FOR AGED RESIDENTS

1. Qulet and peaceful conduct, industry and cleanliness is the duty of every resident, and the explicit comoliance with the rules and directions of the officers, nurses and attendants is enjoined upon all and will be exacted.

2. Residents are not allowed to ingure or in any way destroy their clothing, bedding, or anything belonging to or being about the Home for the Aged; nor will they be allowed to mark, so11, or deface the walls or any other part of the building or oremises.

3. Residents are not allowed to leave the premises without a oass issued by the Suoervisor of Nurses or the SuperIntendent.

4. Soltting on the floors and radiators is strictly forbidden. Smoking in bed is orohibited. All residents should aid in preventing fires.

5. The religious sentiments of every resident shell be respected. In case of illness, the request of any resicent for the ministrations of a clergyman of any denomination, shell be oromptly granted. The Clergy shall have free access to ail wards regardless of hours.

6. All residents must confine themselves to the building and grounds assigned to them for their respective uses.

7. The Suoerintendent of the Home for the Aged and Infirm has full authority to discharge residents from the Home for the Aged for cause.

February 25, 1941. 